\section{Citrus leprosis virus $C$ Infection Results in Hypersensitive-Like Response, Suppression of the JA/ET Plant Defense Pathway and Promotion of the Colonization of Its Mite Vector}

\author{
Gabriella D. Arena ${ }^{1,2,3}$, Pedro L. Ramos-González ${ }^{1,4}$, Maria A. Nunes ${ }^{1}$, \\ Marcelo Ribeiro-Alves ${ }^{5}$, Luis E. A. Camargo ${ }^{2}$, Elliot W. Kitajima ${ }^{2}$, Marcos A. Machado ${ }^{1}$ \\ and Juliana Freitas-Astúa ${ }^{4,6 *}$
}

1 Laboratório de Biotecnologia de Citros, Centro APTA Citros Sylvio Moreira, Instituto Agronômico de Campinas, São Paulo, Brazil, ${ }^{2}$ Escola Superior de Agricultura Luiz de Queiroz, Universidade de São Paulo, São Paulo, Brazil, ${ }^{3}$ Universidade Estadual de Campinas, São Paulo, Brazil, ${ }^{4}$ Laboratório de Bioquímica Fitopatológica, Instituto Biológico, São Paulo, Brazil,

OPEN ACCESS ${ }^{5}$ Instituto Nacional de Infectologia, Fundação Oswaldo Cruz, Rio de Janeiro, Brazil, ${ }^{6}$ Embrapa Mandioca e Fruticultura, Cruz das Almas, Brazil

Edited by:

Abdul Latif Khan,

University of Nizwa, Oman

Reviewed by:

Javier Plasencia,

National Autonomous University of

Mexico, Mexico

Marc Tad Nishimura,

Colorado State University, USA

*Correspondence:

Juliana Freitas-Astúa

juliana.astua@embrapa.br

Specialty section:

This article was submitted to

Plant Biotic Interactions,

a section of the journal

Frontiers in Plant Science

Received: 19 July 2016 Accepted: 08 November 2016 Published: 25 November 2016

Citation:

Arena GD, Ramos-González PL,

Nunes MA, Ribeiro-Alves $M$,

Camargo LEA, Kitajima EW,

Machado MA and Freitas-Astúa J (2016) Citrus leprosis virus C Infection

Results in Hypersensitive-Like Response, Suppression of the JAVET

Plant Defense Pathway and

Promotion of the Colonization of Its Mite Vector. Front. Plant Sci. 7:1757.

doi: 10.3389/fpls.2016.01757
Leprosis is a serious disease of citrus caused by Citrus leprosis virus C (CiLV-C, genus Cilevirus) whose transmission is mediated by false spider mites of the genus Brevipalpus. CiLV-C infection does not systemically spread in any of its known host plants, thus remaining restricted to local lesions around the feeding sites of viruliferous mites. To get insight into this unusual pathosystem, we evaluated the expression profiles of genes involved in defense mechanisms of Arabidopsis thaliana and Citrus sinensis upon infestation with non-viruliferous and viruliferous mites by using reverse-transcription qPCR. These results were analyzed together with the production of reactive oxygen species (ROS) and the appearance of dead cells as assessed by histochemical assays. After interaction with non-viruliferous mites, plants locally accumulated ROS and triggered the salicylic acid (SA) and jasmonate/ethylene (JA/ET) pathways. ERF branch of the JA/ET pathways was highly activated. In contrast, JA pathway genes were markedly suppressed upon the CiLV-C infection mediated by viruliferous mites. Viral infection also intensified the ROS burst and cell death, and enhanced the expression of genes involved in the RNA silencing mechanism and SA pathway. After 13 days of infestation of two sets of Arabidopsis plants with non-viruliferous and viruliferous mites, the number of mites in the CiLV-C infected Arabidopsis plants was significantly higher than in those infested with the non-viruliferous ones. Oviposition of the viruliferous mites occurred preferentially in the CiLV-C infected leaves. Based on these results, we postulated the first model of plant/Brevipa/pus mite/cilevirus interaction in which cells surrounding the feeding sites of viruliferous mites typify the outcome of a hypersensitive-like response, whereas viral infection induces changes in the behavior of its vector.

Keywords: cilevirus, herbivory, plant-virus-vector interaction, Brevipalpus mites, Arabidopsis, Citrus sinensis, hormonal crosstalk, RNA silencing 


\section{INTRODUCTION}

Most of the known plant viruses systemically infect their main plant hosts. Distinctively, Citrus leprosis virus C (CiLV-C), the causal agent of citrus leprosis, is unable to move long distances within any of its almost 50 natural or experimental host species belonging to at least 28 distant plant families (León et al., 2008; Nunes et al., 2012a,b; Arena et al., 2013; Garita et al., 2013, 2014). CiLV-C infection invariably produces chlorotic or necrotic lesions around the feeding sites of its mite vector. However, albeit it shows localized symptoms, citrus leprosis threatens citrus production in the Americas (Roy et al., 2015). Indeed, it is regarded as the most important viral disease affecting citrus in Brazil, the leading sweet orange producer in the world (Bastianel et al., 2010).

CiLV-C is the type member of the genus Cilevirus (LocaliFabris et al., 2011). Virions are enveloped rod-like particles with $50-55 \times 120-130 \mathrm{~nm}$ and its genome consists of two positive (+) sense single-stranded RNA molecules that contain $5^{\prime}$ cap structures and $3^{\prime}$ poly(A) tails. ORFs in the RNA1 (8745 nt) encode the RNA-dependent RNA polymerase and the putative $29 \mathrm{kDa}$ coat protein. RNA2 contains four ORFs encoding the putative movement protein (MP), which shows conserved motifs of the plant virus MPs of the $30 \mathrm{~K}$ superfamily, and the P15, P61, and P24 proteins with unknown functions (Locali-Fabris et al., 2006; Pascon et al., 2006). However, P61 and P24 display distant homology with structural proteins of the insect-specific negeviruses (Kuchibhatla et al., 2014).

False spider mites of the genus Brevipalpus (Acari: Tenuipalpidae) are polyphagous and cosmopolitan pests that colonize, in addition to citrus, several economically important crops and ornamentals plants (Childers et al., 2003a; Kitajima et al., 2010). In order to feed, false spider mites pierce and conceivably inject saliva into the plant mesophyll cells using their interlocked stylet, and after withdrawing it, they suck out the overflowed cell content of punctuated cells through the preoral cavity (Alberti and Kitajima, 2014). Brevipalpus spp. are haploid during their entire life-cycle, reproduce through thelytokous parthenogenesis and their adult populations are essentially females due to the presence of the endosymbiont bacterium Cardinium sp. (Weeks et al., 2001). Within the group of Brevipalpus species that transmit plant viruses, B. yothersi (synonym B. phoenicis Geijskes citrus type) is the main vector of the cileviruses (Beard et al., 2015; Sánchez-Velázquez et al., 2015; Ramos-González et al., 2016). Once acquired during any of the active phases of these mites, CiLV-C is persistently transmitted to distant parts within the same plant and to new ones, but not to their offspring (Bastianel et al., 2010; Kitajima and Alberti, 2014). CiLV-C replication in B. yothersi has been suggested (Roy et al., 2015).

Plants are recurrently invaded by attackers with distinct infecting or feeding strategies. Upon detection of the attackerassociated ligands, i.e., pathogen-associated molecular patterns (PAMP) and/or effectors, the plant immune system triggers a spectrum of dynamic responses to arrest the colonization process (Thomma et al., 2011; Cui et al., 2015). Phytohormones such as salicylic acid (SA), jasmonic acid (JA) and ethylene (ET) mediate a transcriptional reprogramming, tuning up defense responses that are modulated by the nature of the injury (Arimura et al., 2011; Pieterse et al., 2012; Alazem and Lin, 2015). The SA signaling pathway is primarily induced in response to biotrophic pathogens and piercing-sucking herbivores that cause minimal tissue damage. The JA pathway is subdivided in two antagonistic and interconnected branches that are activated in response to distinct stimuli. The ethylene responsive factorbranch (ERF-branch) is regulated by ERF transcription factors and synergistically cross-communicates with the ET pathway in response to necrotrophic invaders. On the contrary, MYCbranch, controlled by MYC transcription factors, is independent of ET and mediates defense against herbivores whose action greatly disrupts tissue integrity. Typically, SA antagonizes the JA/ET pathways, a plant strategy to efficiently allocate its resources according to the nature of the attack (Pieterse et al., 2012).

Plant defense against viruses mainly involves the RNA silencing machinery (Mandadi and Scholthof, 2013; Pumplin and Voinnet, 2013). Double stranded RNA (dsRNA) replication intermediates or structured RNA genomes from viruses can be considered a special case of PAMP, i.e., VAMP (virusassociated molecular pattern). VAMPs are recognized by Dicerlike nucleases (DCL), which further process them into virusderived siRNAs. A guide strand of these molecules and an AGO protein are assembled into the RNA-induced silencing complex (RISC), which direct specific silencing of the homologous viral genome (Parent et al., 2012). Albeit previously considered an independent mechanism of antiviral resistance, the current understanding is that RNA silencing is connected with the hormonal pathways through the SA- and JA-induced RNAdependent RNA polymerase 1 protein (RDR1) (Hunter et al., 2013).

In addition to hormones, plant response also involves the generation of reactive oxygen species (ROS). ROS may act as signal transduction molecules in the host, as toxic compounds against the attackers or as a blocking agent to their colonization by promoting the reinforcement of the plant cell walls (Foyer and Noctor, 2013; Camejo et al., 2016; Gilroy et al., 2016). Moreover, ROS accumulation may lead to the activation of the hypersensitive response (HR) (Foyer and Noctor, 2005; Xia et al., 2015). ROS and SA pathways are interconnected and mutually enhanced, promoting a self-amplifying feedback loop that drives HR (Xia et al., 2015). Hypersensitive-like response can also be observed as an outcome of plant-attacker interactions where the typically involved effectors and ligands are missing, suggesting the participation of yet unknown host proteins (Li et al., 2010).

Plant defenses are constantly challenged, and even hijacked, by the mechanisms of virulence from evolved attackers. Hormonal cross-talking that usually occurs during the plant immune response can be wielded by the attackers for their own benefit (Pieterse et al., 2012). In contact with plants, some insect eggs induce high level of SA, leading to a strong reduction of the JA-mediated defenses and, hence, decreasing their interference on the future larva feeding (Little et al., 2007; Bruessow et al., 2010; Gouhier-Darimont et al., 2013; Hilfiker et al., 2014). Extracts from these eggs reduce the MYC 
protein levels in a SA-dependent manner (Schmiesing et al., 2016). Moreover, insects and mites secrete proteins in their saliva which modulate, and even suppress, the plant defense response (Kant et al., 2015; Villarroel et al., 2016). In the saliva, proteins from arthropod-associated microorganisms, i.e., endosymbiont bacteria and viruses, are also responsible for plant defense elicitation (Chaudhary et al., 2014; Jaouannet et al., 2015). Similarly, plant viruses encode suppressors to efficiently overcome the RNA silencing (Li and Ding, 2006). Virus derived proteins have also been implicated in mutual benefit to pathogens and their vectors (Casteel and Falk, 2016).

Despite the uniqueness of the citrus leprosis pathosystem, its molecular aspects are poorly understood. To extend our comprehension of the mechanisms underlying it, the current study evaluated the model plant Arabidopsis thaliana by profiling the mRNA expression of marker genes of the main defense pathways during the course of its interaction with both nonviruliferous and CiLV-C viruliferous Brevipalpus mites using RT-qPCR. Moreover, we searched for evidence of an HR by performing histological tests on the injured plant tissues. Finally, we evaluated the feasibility of using Arabidopsis as a model host for citrus leprosis studies by comparing the transcript profiles of some selected Arabidopsis genes with their homologs of Citrus sinensis. In addition to the first evidence on how plants respond to both Brevipalpus feeding and CiLV-C infection, we present evidence of changes in the behavior of the vector mites in CiLV$\mathrm{C}$ infected plants. Additionally, we provide data about CiLV-C inoculation efficiency by the mite and indicate the plant reference genes to be used in the current and future transcriptomic studies involving the citrus leprosis pathosystem.

\section{RESULTS}

\section{An Inoculation Access Period of $6 \mathrm{~h}$ Results in $100 \%$ of CiLV-C-Infected Arabidopsis plants by Viruliferous Brevipalpus yothersi Mites}

Since the successful inoculation of CiLV-C is only achieved using viruliferous mites, the analysis of the transcriptional profiles of plant genes involved in the interaction with this virus can only be inferred by comparing the profiles of plants infested with viruliferous and non-viruliferous mites. However, as upon infestation the mites do not feed in a synchronous manner, the time of CiLV-C inoculation may vary among a set of infested plants. To reduce the impact of phased out infections over the analysis of the expression profiles of genes implicated in the earlier steps of the interaction, we conducted a preliminary experiment to determine the minimal feeding period necessary to achieve $100 \%$ of infection of plants infested with viruliferous mites. Seven to ten days after infestation (dai), Arabidopsis plants inoculated with viruliferous mites either for 4 or $6 \mathrm{~h}$ showed the typical symptoms of CiLV-C infection; i.e., chlorotic spots in green leaves and green islands in yellow senescent ones (Arena et al., 2013) (symptoms as in Figure 1). However, the number of symptomatic plants differed between the two treatments. In the $4 \mathrm{~h}$ treatment only $30 \%$ of the plants displayed symptoms

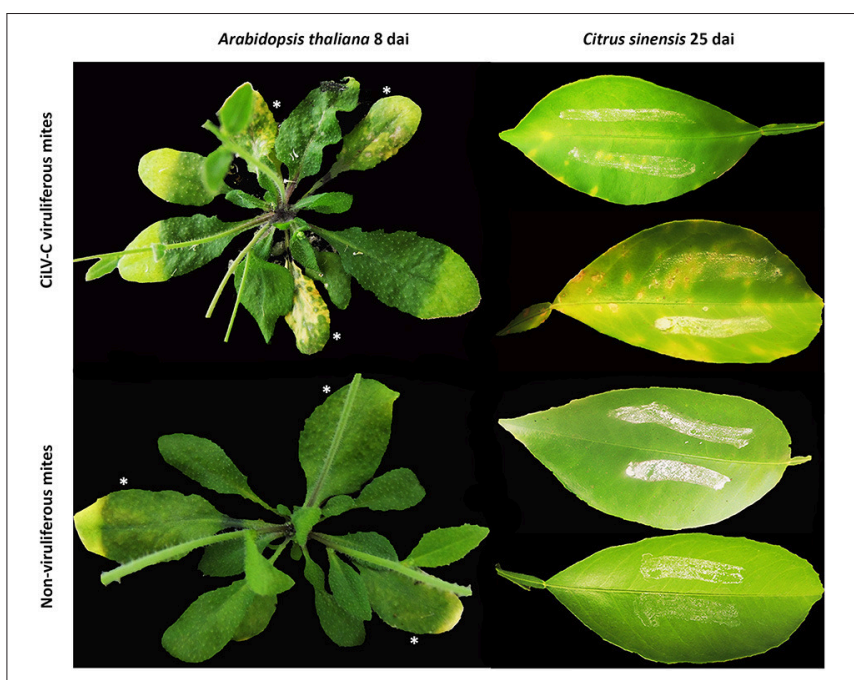

FIGURE 1 | Phenotypes of Arabidopsis thaliana (left) and Citrus sinensis (right) plants infested with non-viruliferous and CiLV-C viruliferous Brevipalpus yothersi mites during the time course experiments. Pictures from Arabidopsis and $C$. sinensis were taken at 8 and 25 days after infestation, respectively. Infested leaves are indicated by asterisks $\left({ }^{*}\right)$.

TABLE 1 | CiLV-C inoculation efficiency of Arabidopsis thaliana with five viruliferous Brevipalpus mites after different inoculation access periods (IAP).

\begin{tabular}{lcccc}
\hline IAP & $\begin{array}{c}\text { Test-plants } \\
(\mathbf{n})\end{array}$ & $\begin{array}{c}\text { Symptomatic } \\
\text { plants }(\mathbf{n})\end{array}$ & $\begin{array}{c}\text { PCR-positive } \\
\text { plants } \mathbf{( n )}\end{array}$ & $\begin{array}{c}\text { Inoculation } \\
\text { efficiency (\%) }\end{array}$ \\
\hline $4 \mathrm{~h}$ & 10 & 3 & 3 & 30 \\
$6 \mathrm{~h}$ & 10 & 10 & 10 & 100 \\
Control $^{\mathrm{a}}$ & 10 & 10 & 10 & 100
\end{tabular}

alnoculation positive control, where CiLV-C viruliferous mites were kept onto plants throughout the experiment.

${ }^{b}$ Plants were evaluated by RT-PCR using primer pairs designed for a region within the CiLV-C MP gene (Locali et al., 2003).

compared to $100 \%$ in the $6 \mathrm{~h}$ treatment (Table 1). Presence of CiLV-C in all symptomatic plants was confirmed by RT-PCR (data not shown). Thus, from these analyses we determined that $6 \mathrm{~h}$ was an appropriate time to initiate the evaluation of the Arabidopsis responses to CiLV-C infection.

\section{F-BOX, SAND and TIP41 Are Suitable Reference Genes for Transcript Normalization during Arabidopsis/Mite/Cilevirus Interaction}

A time course experiment to evaluate Arabidopsis interaction with non-viruliferous and viruliferous mites was set up. Six candidate reference genes (EF1A, F-BOX, GAPDH, PPR, SAND, and TIP41) for transcript normalization were evaluated by assessing their expression levels. Quantification cycle (Cq)-values ranged from 23.98 to 36.01 (Table 2), and only those whose transcripts accumulated in moderate quantities $(15<\mathrm{Cq}<$ 30, Wan et al., 2010) were further selected (i.e., EF1A, F$B O X, G A P D H, S A N D$, and TIP41). Statistical analysis using 
TABLE 2 | Arabidopsis thaliana candidate reference genes ranked according to their expression stability.

\begin{tabular}{llccc}
\hline Gene & Locus & Mean Cq $( \pm \boldsymbol{S D})^{\mathbf{a}}$ & ${\text { Stability value }(\boldsymbol{M})^{\mathbf{b}}}$ & Ranking $^{\mathbf{b}}$ \\
\hline FBOX & AT5G15710 & $30.46 \pm 0.29$ & 0.18 & 1 \\
TIP41 & AT4G34270 & $28.15 \pm 0.31$ & 0.18 & 1 \\
SAND & AT2G28390 & $28.30 \pm 0.26$ & 0.19 & 2 \\
EF1 $\alpha$ & AT5G60390 & $23.98 \pm 0.38$ & 0.22 & 3 \\
GAPDH & AT1G13440 & $30.19 \pm 0.71$ & 0.34 & 4 \\
PPRC & AT5G55840 & $36.01 \pm 0.41$ & - & -
\end{tabular}

aQuantification cycle (Cq) and standard deviation (SD) values were obtained from RTqPCR of 27 samples (three technical replicates of nine biological samples across three experimental conditions: plants infested with viruliferous mites, non-viruliferous mites or not infested).

${ }^{b} M$-values, calculated by geNorm (Vandesompele et al., 2002) based on RT-qPCR data, increase from the most stable pair of genes to the least stable.

${ }^{c}$ PPR gene was excluded from analyses due to its low expression level (Cq-value > 35).

geNorm (Vandesompele et al., 2002) revealed that the F-BOX, $S A N D$, and TIP41 genes presented the lowest $M$-values, which correspond to the highest expression stabilities. Since data normalization is preferably done using at least three reference genes (Vandesompele et al., 2002), these were selected for the RT-qPCR analysis conducted in this work.

\section{Infestation with Non-viruliferous Mites Induces the SA Pathway and a Response against Necrotrophic Rather than Herbivorous Attackers in Arabidopsis}

Expression of several genes involved in SA response (ICS1, EDS5, NPR1, WRKY70 and PR5), JA/ET pathways (ETR1, EIN2, MYC2, and $P D F 1.2)$ and gene silencing mechanism (AGO2), in addition to marker genes for HR (NHL10) were induced as soon as at $6 \mathrm{~h}$ after infestation (hai) (Figure 2), indicating a rapid and combined response of the plants to the mites.

Genes of the SA pathway remained induced throughout the time course, i.e., ICS1: encoding the enzyme responsible for main SA biosynthesis in defense responses, EDS5: the transporter of SA from the chloroplast to cytoplasm, NPR1: the main regulator of SA-responsive genes and the transcription factor (TF) WRKY70. While statistical analysis indicated an induction of the defense gene PR5 as early as 6 hai, the expression of this gene as well as that of $P R 1$ were noticeably up-regulated at 8 dai (Figure 2).

The expression of most of the evaluated genes of the JA/ET pathways was also induced at least at one time point with the exception of JAR1, whose relative expression was not altered at the earlier times of the infestation and was reduced at 8 dai (Figure 2). Up-regulation of the ethylene receptor gene (ETR1) was observed at 6,12 hai and 8 dai; while induction of the main positive regulator downstream of the ethylene perception (EIN2) was detected at 6 hai and 8 dai. Up-regulation of the TF MYC2 was detected at 6 hai, but its relative expression was gradually reduced at the following two time points and increased again at 8 dai. The relative expression of the genes PDF1.2 and VSP2 increased during the interaction, although at different levels and time points. Induction of PDF1.2 was noteworthy since its transcript levels were 500 -fold higher than in not infested plants (Figure 2).

Expression of genes of the RNA silencing mechanism was also modulated in response to mite feeding (Figure 2). Induction was verified for RDR1 (12 hai), AGO2 (6 hai) and DCL2 (12 hai). We also observed repression of $A G O 1$ at 12 hai, of HEN1 and RDR6 at 12 hai and 8 dai, and of DCL4 at 6, 12 hai and 8 dpi.

RBOHD gene, which encodes a NADPH oxidase enzyme responsible for ROS production, was highly induced at 8 dai, whereas the HR specific gene NHL10 was found upregulated throughout the time points assessed, except at 24 hai (Figure 2).

\section{Arabidopsis Infestation with CiLV-C Viruliferous B. yothersi Mites Enhances SA Response and Suppresses the JA/ET Pathway}

CiLV-C loads during the time course experiment were assessed using a RT-qPCR assay established during this work. Virus was detected in all plants infested with viruliferous mites, whereas its absence was confirmed in plants either infested with nonviruliferous mites or non-infested. In the subset of plants collected at 12 and 24 hai, virus titers were ca. 2-fold higher ( $p$ $<0.05)$ than in plants collected at 6 hai, whereas at the time of symptom appearance (8 dai), the viral load increased 2000 -fold (Figure 3A).

Overall, the expression of the SA pathway related genes were higher in plants infested with viruliferous mites than in those infested with non-viruliferous ones (Figure 2). For instance, the expression of genes coding for proteins acting upstream of the pathway (ICS1 and EDS5) was triggered in higher levels as early as 6 hai, whereas those encoding downstream proteins were gradually up-regulated. Induction of the TF TGA3 and the defense protein PR5 were observed in samples collected at 12 hai. In the case of $W R K Y 70, N P R 1$, and $P R 1$, maximum relative expressions were detected at the latest stage of the infection (8 dai), when the highest viral loads were reached (Figure 3A).

In contrast to the general activation of genes of the SA pathway, genes of the JA/ET pathways displayed distinct expression patterns (Figure 2). Upon infection, genes encoding the receptors for JA (JAR1) and ET (ETR1) were up-regulated, although the expression levels of downstream genes of this pathway were reduced. EIN2 and MYC2 were repressed at 6 and 12 hai, respectively, whereas the relative expression of the pathway outcome genes PDF1.2 and VSP2 showed a marked reduction at the end of the evaluation.

Core genes of the RNA silencing mechanism showed distinct expression profiles in plants infested with non-viruliferous compared to those infested with viruliferous mites (Figure 2). RDR6 and HEN1 were induced earlier (6 and 12 hai, respectively) than AGO2 (8 dai), whereas the Dicer-like nucleases genes were suppressed during the infection. The lowest relative expressions of DCL2 and DCL4 were detected at 12 hai and 8 dai, respectively.

The expression patterns of the marker genes of the ROS burst and HR were up-regulated in response to virus infection. 

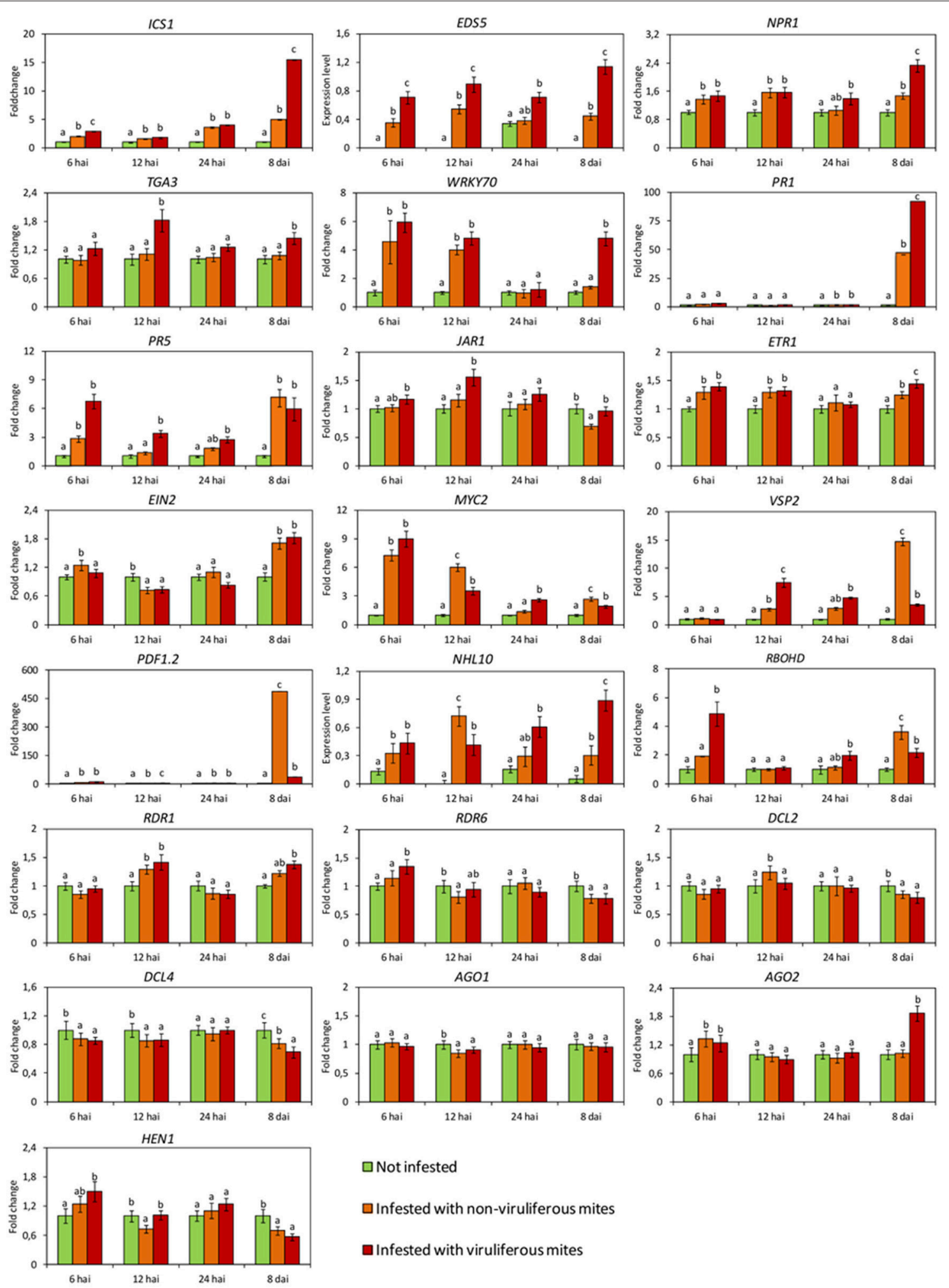

$\square$ Not infested

口Infested with non-viruliferous mites

anfested with viruliferous mites

FIGURE 2 | Expression profiles of Arabidopsis thaliana genes involved in the main plant defense pathways assessed by RT-qPCR. In green, plants kept without mites. In orange, plants infested with non-viruliferous mites. In red, plants infested with CiLV-C viruliferous mites. Data are presented as fold change values in comparison with not infested plants (with fold change value set to 1) or expression levels when transcripts were not detected in not infested plants. Values represent the mean of 10 biological replicates for each set. Error bars represent standard errors. Different letters correspond to different expression levels between treatments within the same time point (ANOVA and Tukey's HSD post-hoc test, $\alpha<0.05$ ). hai, hours after infestation; dai, days after infestation. 

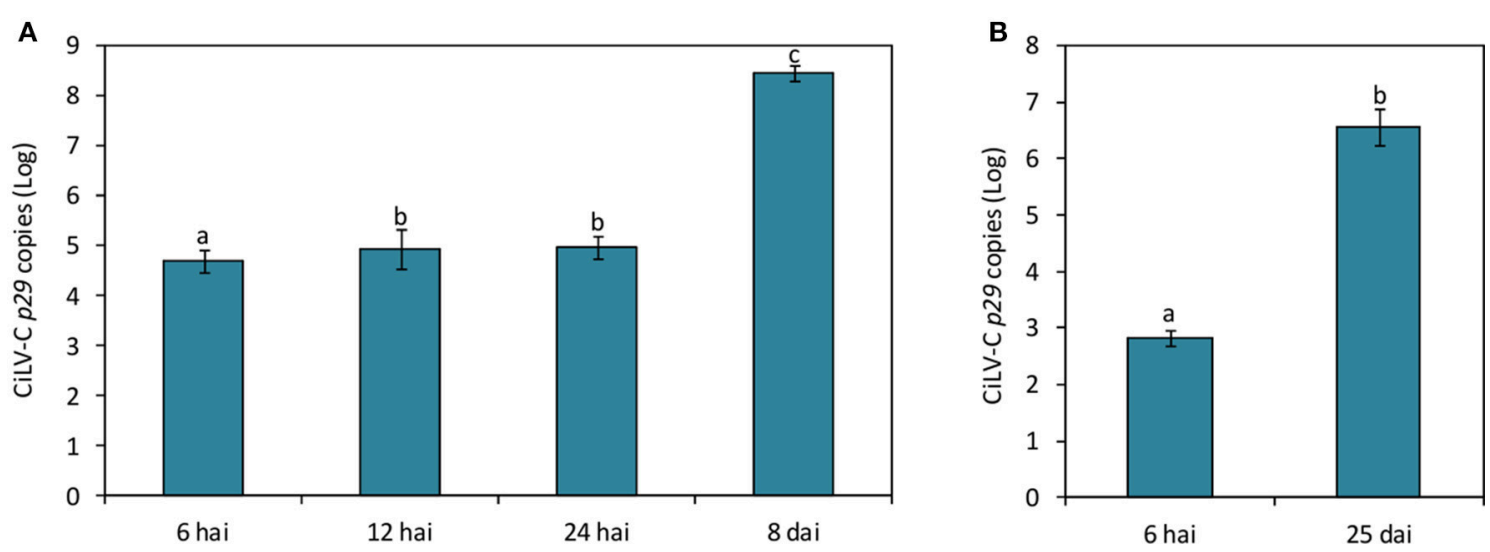

FIGURE 3 | CiLV-C loads on Arabidopsis thaliana (A) and Citrus sinensis (B) plants infested with viruliferous Brevipalpus yothersi mites throughout the time course of the interaction. Data are presented as absolute number of copies (log) of the CiLV-C p29 gene normalized against SAND genes corresponding to each plant species. Values represent the means of 10 biological replicates for each time point. Standard errors are represented on each bars. Different letters correspond to different number of copies between the time points assessed (ANOVA and Tukey's HSD post-hoc test, $\alpha<0.05$ ).

Induction of $R B O H D$ was observed as early as 6 hai, whereas induction of NHL10 was detected at 8 dai.

\section{Sweet Orange Plant Response to Citrus Leprosis Mirrors Major Hallmarks of the Arabidopsis/Brevipalpus Mite/CiLV-C Interaction}

The expression profiles of some key genes involved in the defense response of Arabidopsis to Brevipalpus mites and CiLV-C (PR1, $M Y C 2, A G O 2$, and WRKY70) were also evaluated in infested sweet orange plants.

In citrus plants infested with viruliferous mites, the virus was detected by RT-qPCR as early as 6 hai (Figure 3B). Viral loads increased around $10^{4}$-fold after 25 days of infection. Symptoms were firstly observed at 17 dai, when small chlorotic spots started to develop in some plants. Typical chlorotic and necrotic lesions of citrus leprosis only were observed at 25 dai (Figure 1).

Differences in gene expression were not observed between not infested plants and those infested with non-viruliferous mites at 6 hai. At this time, only the expression of WRK70 and $A G O 2$ were induced in response to the infestation with viruliferous mites (Figure 4). However, at 25 dai all genes had their expression altered. Particularly, high relative expression of AGO2 was observed on plants infested with viruliferous mites, suggesting a RNA silencing response specific to CiLV$\mathrm{C}$ infection. The SA-dependent PR1 gene was induced both in plants infested with non-viruliferous and viruliferous mites, but in the latter treatment its relative expression was much higher, probably indicating an exacerbated response to the viral infection progress. By contrast, the expression of the JA/ET-related TF MYC2 was induced only in plants infested with non-viruliferous mites, suggesting that its expression is reduced to basal levels upon infection by CiLV-C. The expression of WRKY70, the TF responsible for the SA-JA cross-talk, was induced as a result of mite feeding, but it was higher in plants infected with CiLV-C.

\section{CiLV-C Infection Intensifies the Oxidative Stress and Cell Death in Arabidopsis Plants}

ROS production was detected using the assay based on the oxidation of $3,3^{\prime}$-diaminobenzidine (DAB), which turns brown in the presence of hydrogen peroxide $\left(\mathrm{H}_{2} \mathrm{O}_{2}\right)$. Discrete brownish spots were detected in leaves collected as early as 6 and 12 hai in plants of both mite-infested treatments, and their frequency increased at 24 hai comprising up to 1.5 and $1.9 \%$ of the stained tissue area in plants infested with non-viruliferous and viruliferous mites, respectively (Figures 5A,B). DAB stained area concentrated in the leaf midribs, which correspond to preferred mites feeding regions. At 8 dai, the number of spots increased and they were observed alongside the leaves as well (Figure 5C). Brownish areas were noticeably larger and more frequently seen in virus-infected leaves, representing approximately $25.6 \%$ of the leaf area. In plants infested with non-viruliferous mites the stained tissue only represented $4.5 \%$ of the leaf. $\mathrm{H}_{2} \mathrm{O}_{2}$ production was not observed in non-infested plants.

In infested plants, dead cells were detected since 6 hai and they increased in number over time as revealed by trypan blue dying (Figure 5D). Foci of dead cells were mostly confined to the leaf main veins and chiefly corresponded to individual cells during the early times of the interaction (6-24 hai). Leaves of plants infested with viruliferous mites presented a higher frequency of blue spots and these were larger as they likely involved greater number of cells. As observed in the accumulation of $\mathrm{H}_{2} \mathrm{O}_{2}$, spots of dead cells were scattered throughout the virus-infected leaves at 8 dai. No stain was detected in leaves of the healthy control plants.

\section{CiLV-C Infection in Arabidopsis Modules the Behavior of Brevipalpus Mites}

To evaluate the putative role of $\mathrm{CiLV}-\mathrm{C}$ infection over the behavior of Brevipalpus mites, two sets of healthy Arabidopsis plants were infested with two populations of either viruliferous or non-viruliferous adult mites. Typical localized symptoms 


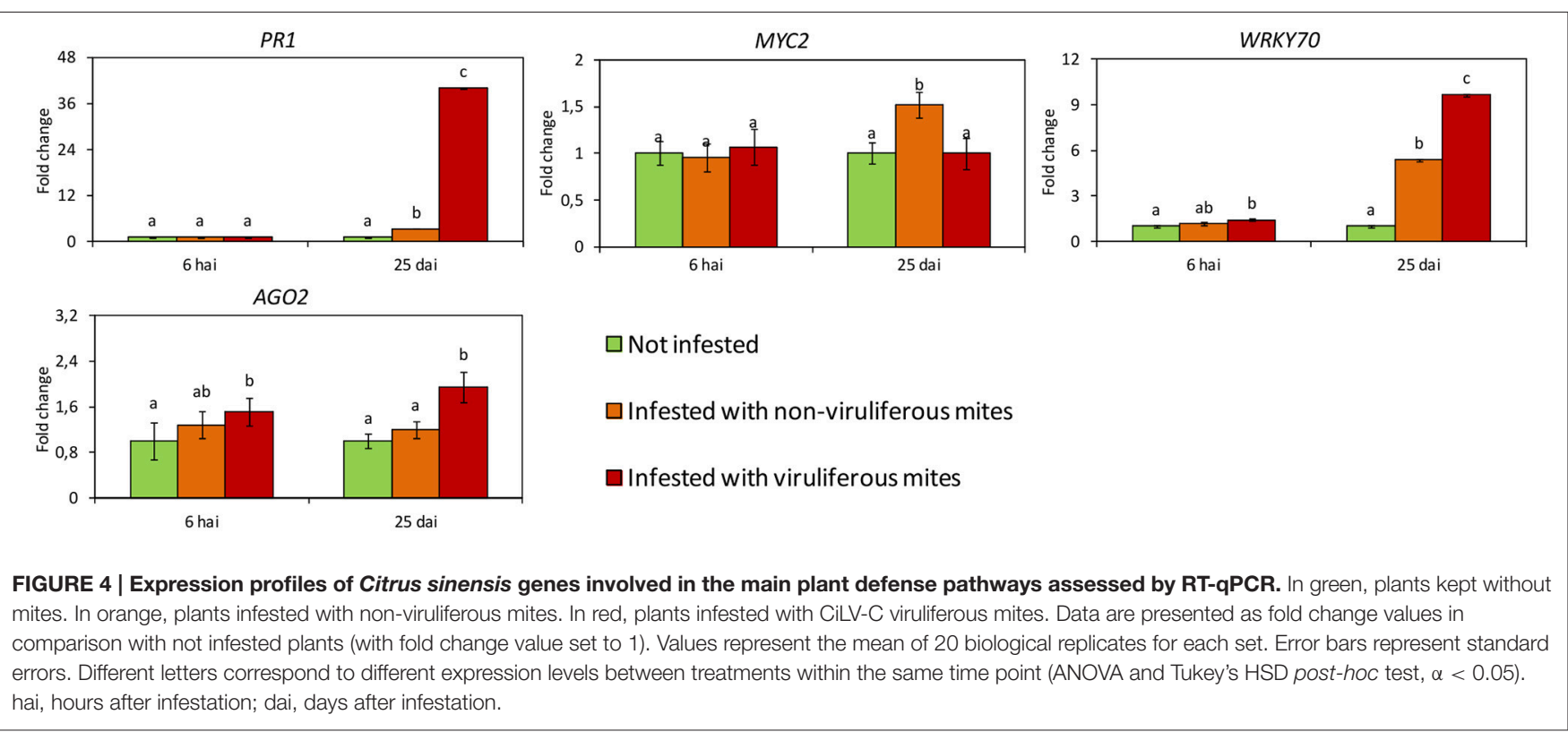

started to appear at 7 days after infestation with viruliferous mites only. After 13 days of infestation, the number of mites per plant was higher in those infested with viruliferous ones $(p<0.01)$ (Supplementary Table 2, Figure 6). While no significant differences in mite numbers were observed between primarily and secondary infested leaves in plants that received viruliferous mites $(p>0.05)$, the non-viruliferous mites were unevenly distributed throughout the infested plants, with higher population densities found in the secondary infested leaves $(p<0.05)$. The total number of mite eggs counted in the two sets of plants did not differ significantly $(p>0.05)$. However, the number of eggs in the primarily infested leaves was superior to that in the secondary infested leaves $(p<0.01)$ for those plants infested with viruliferous mites, whereas no such differences were observed for plants infested with non-viruliferous mites $(p>0.05)$.

\section{DISCUSSION}

In this work we provide insights into plant response during citrus leprosis infection, an emergent viral disease that threatens citrus production in the Americas (Roy et al., 2015). Remarkably, this disease reveals an atypical pathosystem in which its etiological agent, CiLV-C, does not systemically spread in the host plants and half of the genes encoded by its genome are considered as orphans since they have no homologs in other viral species (Locali-Fabris et al., 2006; Tautz and Domazet-Lošo, 2011). Additionally, Brevipalpus yothersi mites, the CiLV-C vector, also attack hundreds of plant species of very distinct families, have worldwide distribution and exhibit an unusual biology (Weeks et al., 2001; Childers et al., 2003b).

To shed light on citrus leprosis pathosystem, we evaluated the transcriptional profiles of marker genes of Arabidopsis defense pathways, ROS production and the occurrence of cell death upon infestation with either non-viruliferous or CiLV-C viruliferous mites. Moreover, we extended these analyses to sweet orange in order to validate the use of Arabidopsis as a model plant for the study of citrus leprosis.

As a result of the interaction of Arabidopsis with nonviruliferous mites, small areas likely involving a few dead cells proliferated in infested leaves while increased amounts of $\mathrm{H}_{2} \mathrm{O}_{2}$ were detected within early stages of the interaction. Such a pattern of dead cell patches may be a direct consequence of mite feeding and resembles that observed during interaction of the mite Tetranychus urticae with Arabidopsis and bean plants in which only one cell is targeted by the mite's stylet (Bensoussan et al., 2016). Brevipalpus activity also elicited the expression of SA pathway genes (biosynthesis, signaling and response), and the JA/ET responsive genes PDF1.2 and VSP2. Notably, the expression level of PDF1.2 was much higher than that of VSP2, ca. 500- and 15-fold, respectively, in comparison to the not infested treatment at 8 dai.

The switching between strong and mild expression levels of the JA-responsive genes was previously described as an herbivore strategy to rewire the plant response in its favor (Verhage et al., 2011). Based on this, our data supports the hypothesis that $B$. yothersi mites might manipulate plant defenses to their own benefit. Typically, plant response to herbivory and tissue damage triggers the JA signaling pathway, which controls two major acting branches ( $\mathrm{Wu}$ and Baldwin, 2010; Arimura et al., 2011; Erb et al., 2012). Activation of each branch is mediated by several TFs usually represented by MYC2 and ERF1. Whereas the ERF-branch induces the expression of genes such as PDF1.2 to counteract necrotrophic pathogens, the MYC-branch up-regulates genes such as VSP2, which encodes a phosphatase with anti-herbivory activity (Verhage et al., 2011; Kazan and Manners, 2013). TFs from the MYC-branch also interact with TFs of the ERF-branch, and vice versa, repressing each other (Song et al., 2014). Under herbivory attack, wild-type Arabidopsis plants preferably activate the MYC branch; however, 
A
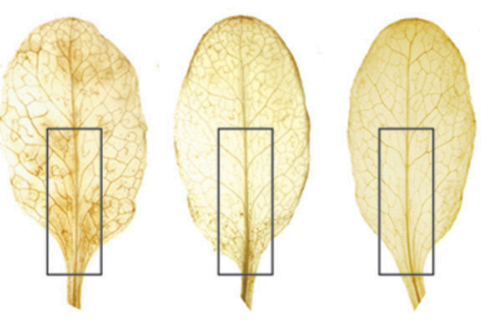

C
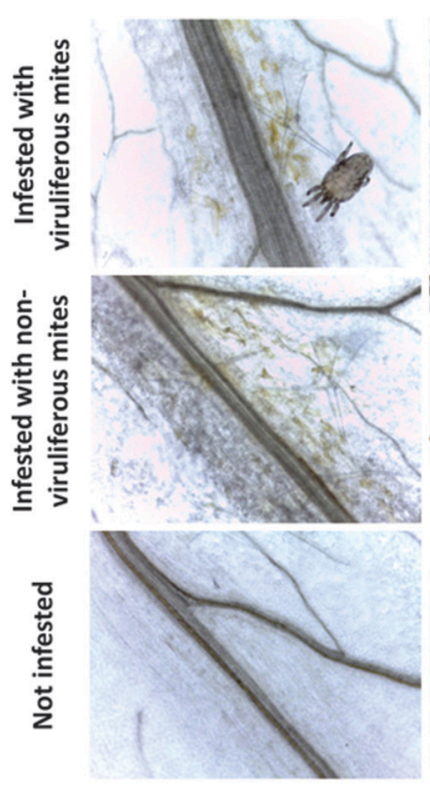

D

6 hai
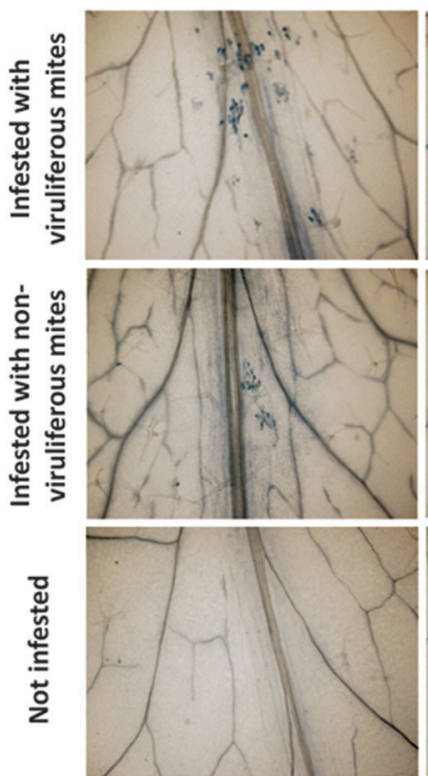

12 hai

12 hai

B
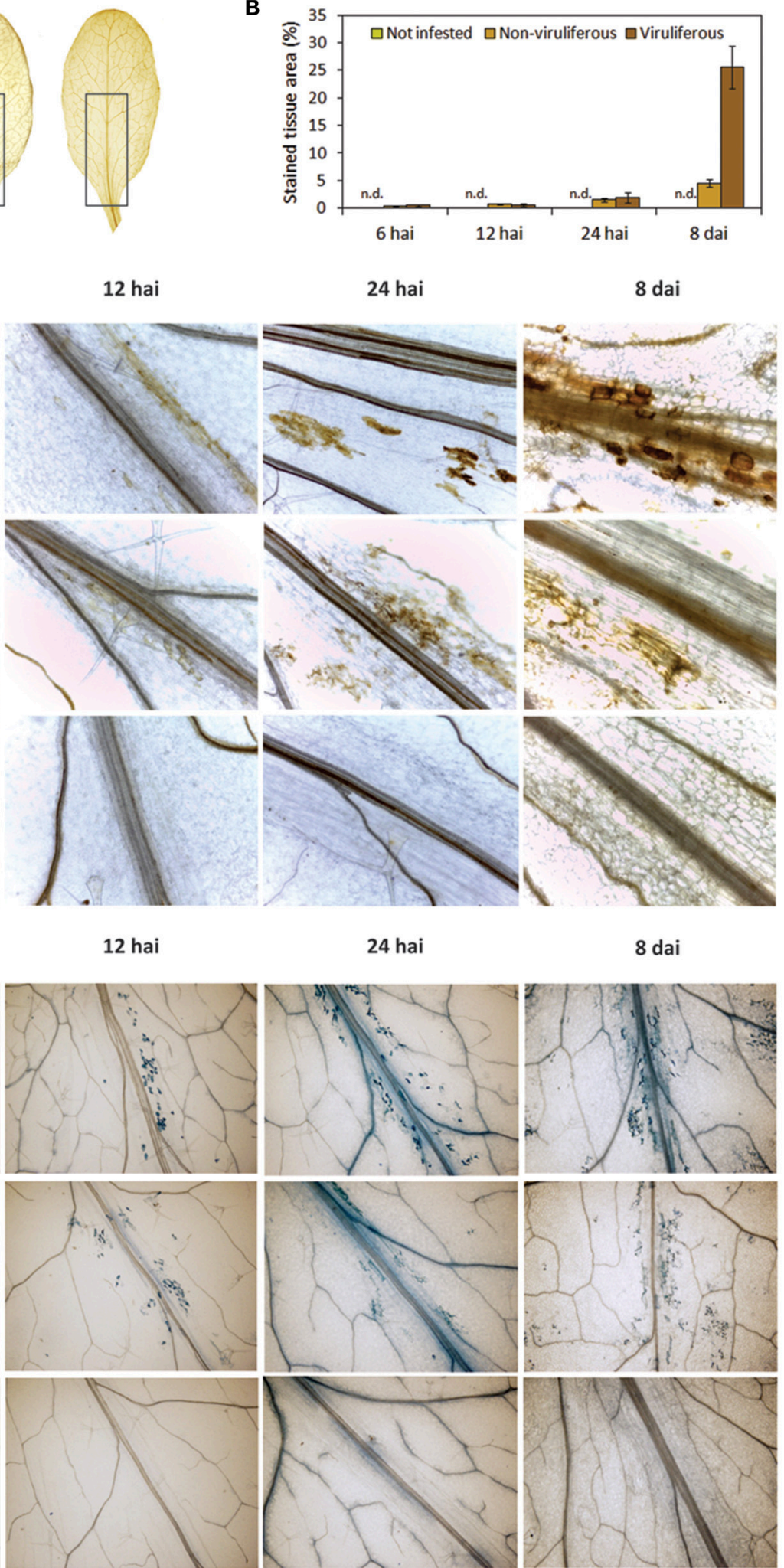

FIGURE 5 | Accumulation of reactive oxygen species (ROS) and cell death in Arabidopsis thaliana plants infested with non-viruliferous and CiLV-C viruliferous Brevipalpus yothersi mites at 6 hours after the infestation (hai), 12 hai, 24 hai, and 8 days after the infestation (dai). (A) Detection of hydrogen 


\section{FIGURE 5 | Continued}

peroxide by $3,3^{\prime}$-diaminobenzidine (DAB) staining at 8 dai on leaves infested with viruliferous mites, non-viruliferous mites and not infested, respectively. Highlights on leaves midribs represent the regions where mites concentrate, used to quantification of stained area. (B) Quantitative measure of DAB brownish areas on highlighted regions along the course of the infestation. Values represent the means of 10 biological replicates for each set. Error bars represent standard errors. (C) Detail of ROS detection in leaves stained with DAB. (D) Detail of cell death in leaves stained with trypan blue.

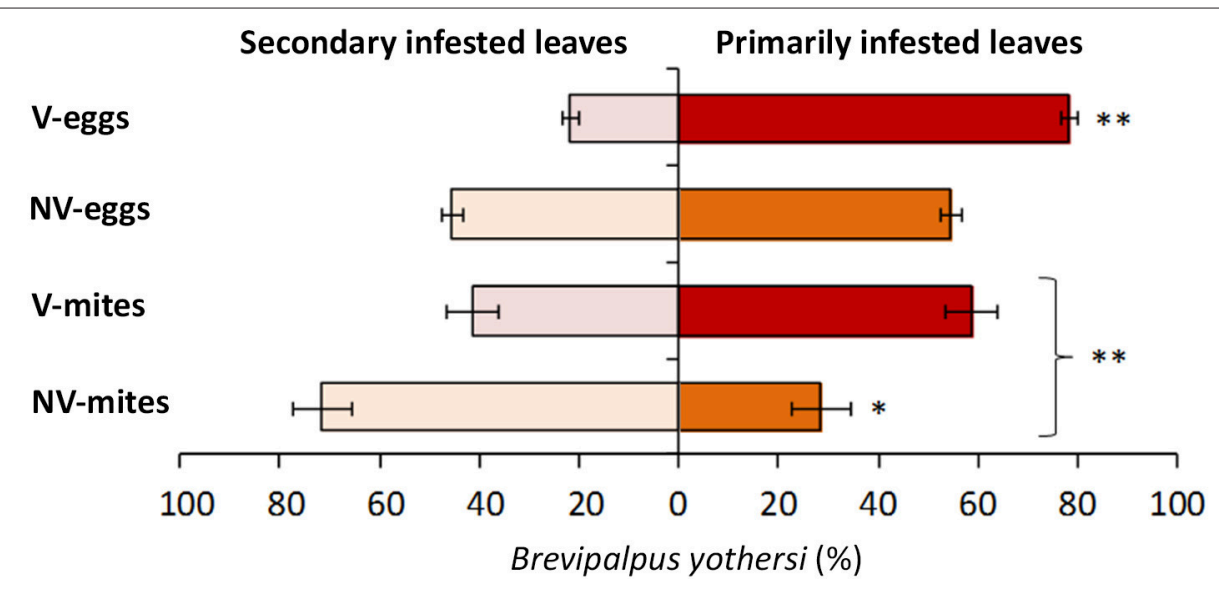

FIGURE 6 | Distribution of Brevipalpus yothersi adult mites and eggs in Arabidopsis thaliana. Non viruliferous (NV) or CiLV-C viruliferous (V) mites were deposited in three leaves of each plant and were counted at 13 days after the infestation. Data are presented as the average percentages of mites or eggs in the primarily infested leaves (where mites were initially deposited) and secondary infested leaves (due to mite migration to contiguous leaves). Error bars represent standard errors. Statistically significant differences at $p<0.05\left(^{*}\right)$ or $<0.01\left(^{* *}\right)$ are indicated. Bracket indicates the comparison between the number of NV and $V$ mites.

activation of the ERF-branch occurs, for instance, in plants impaired in the MYC-branch, as in the case of Arabidopsis jar1-1 mutants (Verhage et al., 2011). In the Arabidopsis-Brevipalpus interaction assessed in this study, the down-regulation of JAR1 was accompanied by an increased expression of PDF1.2 detected at the end of the time course. Therefore, repression of JAR1 could redirect the JA pathway toward PDF1.2 thus reducing the anti-herbivory defense conferred by the MYCbranch.

Arabidopsis infestation with Brevipalpus also triggered SA signaling leading to the up-regulation of $P R$ responsive genes within 24 hai. This has been observed in responses to certain arthropods that cause mild tissue injuries such as the piercingsucking insects like aphids (Zarate et al., 2007; Arimura et al., 2011). By exploiting the natural cross-talk between the SAJA/ET signaling pathways, these herbivores suppress JA mediated defenses favoring their own performance (Zarate et al., 2007; Hogenhout and Bos, 2011; Zhang et al., 2013). When induced, SA down-regulates the transcription of JA responsive genes from both ERF and MYC branches through a mechanism mediated by NPR1 and WRKY70 (Caarls et al., 2015). However, differently than in insects, in plant-mite interactions, both SA and JA/ET signaling pathways are simultaneously induced and apparently do not antagonize each other (Zhurov et al., 2014). Although this could be the case of Brevipalpus-Arabidopsis interaction, where both VSP2 and PDF1.2 were induced at most of the analyzed time points, we cannot exclude that during this interaction SA and JA may actually antagonize each other, although partially, and the JA response we report here is intermediate. Such a relationship was also suggested during plant interaction with Tetranychus mites (Alba et al., 2015).

Modulation of plant response by herbivores has been shown to occur by effector proteins present in their saliva (Hogenhout and Bos, 2011). Piercing-sucking insects puncture and deliver effectors to suppress plant defenses and establish compatible interactions. Application of oral secretions of Pieris rapae caterpillars on Arabidopsis leaves, for example, activates the ERFbranch, suggesting that compounds in the saliva divert plant response favoring the herbivore (Verhage et al., 2011). Analogous to aphids, spider mites also suppress plant defenses (Sarmento et al., 2011; Alba et al., 2015) through delivery of effectors via their saliva (Villarroel et al., 2016). Tetranychus evansi suppresses defense routes in tomato, reducing deterrent compounds to even lower levels than constitutive ones expressed in healthy plants (Sarmento et al., 2011). Brevipalpus feeding involves the piercing of plant tissues, and likely, the injection of saliva inside the host cells through a tube formed between its interlocked stylets (Alberti and Kitajima, 2014). Therefore, our results indicating the induction of signaling pathways associated to herbivore manipulation in Arabidopsis suggest that Brevipalpus might also inject effectors in their hosts through the saliva. Since herbivore host range is likely limited by its ability to suppress effectual plant defenses (Hogenhout and Bos, 2011), it is suggested that generalists are more suppressive of plant defense than specialists (Ali and Agrawal, 2012). Brevipalpus mites are extreme generalists, colonizing a wide range of hosts that includes more than 900 plant species spanning more than a 100 plant families (Childers et al., 2003b). In this regard, the 
repertoire of immune response suppression strategies observed during the interaction with Arabidopsis consistently supports the polyphagia of Brevipalpus mites.

CiLV-C infection in Arabidopsis triggered SA-dependent genes, a common response of plants to biotrophic pathogens (Pieterse et al., 2009). From a general point of view, the patterns of expression of the SA pathway genes resembled those observed after infestation with non-viruliferous mites, though fold changes of some genes such as NPR1 and WRKY70 were higher in the presence of the virus. This activation likely reaches the threshold required to trigger the down-regulation of JA/ET responsive genes. In the presence of CiLV-C, PDF1.2 and VSP2 were drastically repressed (13- and 4-fold lower, respectively) at latest stages of the infection when compared to plants infested with non-viruliferous mites, suggesting the occurrence of SA-JA antagonism.

Infestation of Arabidopsis with CiLV-C viruliferous mites typically caused viral infection in the leaves where mites were deposited (primarily infestation). Viral infection as consequence of a secondary infestation due to mite migration between contiguous leaves were barely detected at 8 dai, as observed in Figure 1, or even after 13 dai, when the final evaluation was performed. Results obtained in this work indicated that infected leaves become more attractive for the mites. In absence of viral infection, mites were preferentially found in the secondary infested leaves. This behavior seem to be logic considering that the area for secondary infestation is the largest, comprising more and newer leaves available for mite colonization. In contrast, in plants infected by viruliferous mites, no differences were observed in their distribution, and leaves showing typical CiLVC localized symptoms harbored the largest number of eggs, indicating the preference for oviposition in infected leaves. Moreover, density of mites (mite/plant) reached higher values in the infected Arabidopsis plants. Interestingly, CiLV-C infected sweet oranges plants seem to be also beneficial for Brevipalpus mite population. In a multifactorial experiment addressed to evaluate the influence of citrus rootstocks on the relationship between the mite Brevipalpus sp. and citrus leprosis disease (Andrade et al., 2013), mite density was significantly higher in CiLV-C infected plants.

Recent studies suggest that some virus-infected plants are more attractive for the viral vector settlements and/or more beneficial to the vector development (Mauck et al., 2012; Casteel et al., 2014; Prager et al., 2015; Su et al., 2015; Casteel and Falk, 2016). Viruses that depend on vectors to move from infected to healthy host plants use this strategy as an effective mean to improve their transmissibility (Belliure et al., 2004; Abe et al., 2012). For instance, infection by Tomato spotted wilt virus (TSWV) induces the SA-mediated pathway, which decreases JAregulated defenses leading to enhanced attractiveness of plants to its vector, the thrips Frankliniella occidentalis (Abe et al., 2012). SA pathway induction by CiLV-C and reduction of JA/ET mediated response reported here, in addition to other unknown mechanisms, may benefit Brevipalpus infestation. This issue is of special significance in the case of the conspicuous nature of the localized colonization of CiLV-C, because relationship with its vector is not only essential for plant to plant transmission, but also to the infection of other parts within the same plant. On the other hand, CiLV-C may act as a helper (effector-like) factor of mite infestation to suppress the plant defenses. However, whether the viral infection mediated by viruliferous mites indeed may help the mite fitness to plant colonization is yet unclear and has been addressed in ongoing experiments.

During Arabidopsis interaction with both non-viruliferous and viruliferous Brevipalpus, fold changes of core genes of the RNA silencing machinery showed low variation and the expression profiles were kept mostly invariable, except in the cases of RDR6 and AGO2, whose expressions were enhanced in response to virus infection at 6 hai and 8 dai, respectively. RISC activity against plant viruses preferentially involves AGO1 and, in case of its suppression, the cell switches to a second layer of defense mediated by AGO2 (Harvey et al., 2011). Increased levels of $A G O 2$ during virus infection have been observed in Arabidopsis during Potato virus X (PVX), Cucumber mosaic virus (CMV), Turnip crinkle virus (TCV), Tobacco rattle virus (TRV), and Turnip mosaic virus (TuMV) infections (Carbonell and Carrington, 2015). Control of AGO2 mRNA levels is mediated by the microRNA miR403 via AGO1 (Harvey et al., 2011). Inactivation of AGO1 by some virus suppressor of RNA silencing (VSRs), e.g., the p38 protein from TCV, leads to the expression of AGO2. TCV-p38 VSR activity is exerted by a WG motif that acts as a hook for AGO1 protein, disabling RISC (Azevedo et al., 2010). Interestingly, a WG/GW motif is also present in the $\mathrm{COOH}$ terminal domain of the CiLV-C RdRp protein, suggesting that the activation of AGO2 reported here could result from the hijacking of AGO1 in an analogous manner as the one described for TCV. Further experiments need to be carried out to test the putative VSR activity derived from CiLV-C proteins.

Plant gene expression during CiLV-C resembles that observed in the course of a plant-virus interaction, where SA pathway and RNA silencing are activated (Mandadi and Scholthof, 2013). The current understanding is that both defense responses act coordinately to counteract viral infection (Alamillo et al., 2006; Lewsey et al., 2010; Jovel et al., 2011; Hunter et al., 2013). SA-mediated defense interacts with RNA silencing through ICS1- and NPR1-dependent up-regulation of RDR1, which participates in the generation of secondary siRNA (Hunter et al., 2013). Evidence of interplay between both defenses against viral infections are increasing in the literature, e.g., Plum pox virus (PPV) infection of Nicotiana tabacum results in the SAmediated potentiation of RNA silencing, thus inhibiting PPV systemic movement (Alamillo et al., 2006). In sour orange plants (Citrus aurantium), Citrus tristeza virus (CTV) accumulation and spread are enhanced when the genes RDR1, NPR1, or DCL2DCL4 are silenced (Gómez-Muñoz et al., 2016). For the CiLV$\mathrm{C} /$ Arabidopsis interaction, the induction of RDR1 corroborates with this mechanism and indicates that the early activation of $\mathrm{SA}$ in response to mite feeding could pre-induce resistance to CiLV-C replication.

As observed during the interaction of Arabidopsis with nonviruliferous Brevipalpus, infestation with $\mathrm{CiLV}-\mathrm{C}$ viruliferous mites also elicited the production of $\mathrm{H}_{2} \mathrm{O}_{2}$. However, in this case both the intensity of histochemical signals and fold changes of $R B O H D$ were higher than in the former case, further confirming 
our conclusion that infection by the virus amplifies the host responses. Moreover, in these plants, the frequency of patches of dead cells was also higher, indicating that the plant actively recognizes the presence of CiLV-C. The oxidative burst both activates cell death at the infection site during $\mathrm{HR}$ and signals defense pathways beyond the infection site (Levine et al., 1994; O'Brien et al., 2012). Thus, the observed cell death during CiLV$\mathrm{C}$ infection may be a consequence of HR which on its turn would limit the systemic colonization of the host. Indeed, characteristic necrotic symptoms of CiLV-C infection resemble the outcome of HR-like, although the evolution up to necrosis shows an atypically slower progression in sweet orange than that expected in case of a typical hypersensitive reaction.

Induction of HR in cells of the vascular tissue of sweet orange leaves was previously proposed as the cause for the non-systemic spread of CiLV-C (Marques et al., 2007, 2010). In this regard, caution has to be taken to interpret these and our own results. Despite the strict relation between cell death and pathogen restriction, evidence that $\mathrm{HR}$ limits viral colonization remains controversial (Coll et al., 2011). Moreover, effectiveness and contribution of MP and other CiLV-C-encoded proteins in the movement of this virus remain unknown. However, regardless of whether or not cell death is responsible for restricting CiLV$\mathrm{C}$ systemic movement, the presence of dead cells in association with ROS production are strong evidence of HR-like response elicitation in lesions surrounding the feeding sites of viruliferous mites.

In line with the integration of the RNA silencing with the classic frame of resistance by PAMP-triggered immunity (PTI) and effector-triggered immunity (ETI) (Pumplin and Voinnet, 2013; Sansregret et al., 2013), it is tempting to speculate that the host plants could recognize CiLV-C during activation or suppression of RNA silencing and summon a classic defense response. Recognition of CiLV-C could be from dsRNA produced by virus replication or secondary siRNA derived from RISC, triggering PTI defenses. Otherwise, plant could trigger an ETI response through R-mediated recognition of the putative VSR. In both cases, activation of the SA may convey to an HRlike response, restricting the virus near the inoculation site by the mite vector. Altogether, sequences of facts here reported during Arabidopsis/CiLV-C interaction, e.g., expression of HRrelated genes, activation of effective defense pathways against viral infections, ROS burst sustained along the infection, localized cell death and pathogen restriction at the infection site, suggest that CiLV-C symptoms are the outcome of a HR-like resistance. Consequently, citrus leprosis should be considered the result of an incompatible rather than a compatible interaction.

Finally, responses of sweet orange to the Brevipalpus feeding and CiLV-C infection mirrored those detected in Arabidopsis. Our analysis revealed the activation of SA- and JA/ETdependent defenses against mite feeding. Upon viral infection on viruliferous mites-infected plants, we observed induction of SA pathway and AGO2-mediated RNA silencing and reduction of the JA/ET defenses. However, the defense response was not established at 6 hai, which indicates a later response of $C$. sinensis. Time of symptoms appearance is likely an indicative of this phenomenon: lesions developed from 17 to 25 dai on the woody perennial C. sinensis, while in the herbaceous Arabidopsis this period was reduced to 7 to 10 dai. Although with a slower progression, the natural host developed a similar pattern of response than Arabidopsis, which validates this species as a model to be used in interaction studies of citrus leprosis disease.

With the results presented here, we propose the first model of Arabidopsis/B. yothersi/CiLV-C interaction (Figure 7). This model represents a starting point to understand the processes leading to the development of citrus leprosis and, possibly, other diseases caused by non-systemic viruses also transmitted by these vectors. Future studies shall aim at complementing the model especially with regards to the lacking components and to the contribution of each hormonal pathway to such conspicuous interaction.

\section{MATERIALS AND METHODS}

\section{Plant Material}

Seeds of the Arabidopsis thaliana ecotype Columbia (Col-0) were obtained from the Arabidopsis Biological Resource Center (ABRC). Seeds were sown in sterilized soil in $100 \mathrm{~mL}$ pots and incubated during 4 days at $4{ }^{\circ} \mathrm{C}$ in a dark chamber. After this, plantlets were transferred to a controlled growth chamber (Adaptis AR A1000, Conviron, Winnipeg, Canada) set at 22 $\pm 2{ }^{\circ} \mathrm{C}$ and with a $12 \mathrm{~h}$ light/dark cycle where they were kept throughout the experiments. Citrus sinensis L. Osbeck cv. Pera plants were grown from seeds under greenhouse conditions.

\section{Mite (Brevipalpus yothersi) Rearing and Infestation}

A population of non-viruliferous mites was obtained from a single female collected from a citrus orchard in the State of Bahia, Brazil, and further confirmed as B. yothersi using phase contrast microscopy as reported elsewhere (Beard et al., 2015). Mites were reared onto unripe fruits of leprosis-immune "Tahiti" acid lime (Citrus latifolia Tanaka). All fruits were previously cleaned, dried and partially submerged in liquid paraffin to prevent desiccation. Mites were transferred to an area of approximately $4 \mathrm{~cm}$ in diameter of the fruit surrounded by a barrier of the pest adhesive Biostop gum (Biocontrole, Indaiatuba, Brazil) prepared with a wet mixture of wheat flour, plaster, and fine sand (1:1:2) (Rodrigues et al., 2007). Viruliferous mites were obtained by rearing the non-viruliferous mites from "Tahiti" acid lime as described above on sweet oranges fruits collected from a citrus grove with high incidence of leprosis caused by the CiLV-C strain SJP (Ramos-González et al., 2016) in São José do Rio Preto, State of São Paulo, Brazil. Mites from both viruliferous and nonviruliferous populations were reared for several generations and periodically evaluated for the presence of CiLV-C by RT-PCR using primer pairs designed for a region within the CiLV-C MP gene (Locali et al., 2003).

\section{Assessment of CiLV-C Inoculation Access Period by Viruliferous B. yothersi Mites}

To define the period needed to achieve $100 \%$ of CiLV-C infection of plants after infestation with viruliferous B. yothersi mites, five viruliferous mites were transferred to each of 10 Arabidopsis 


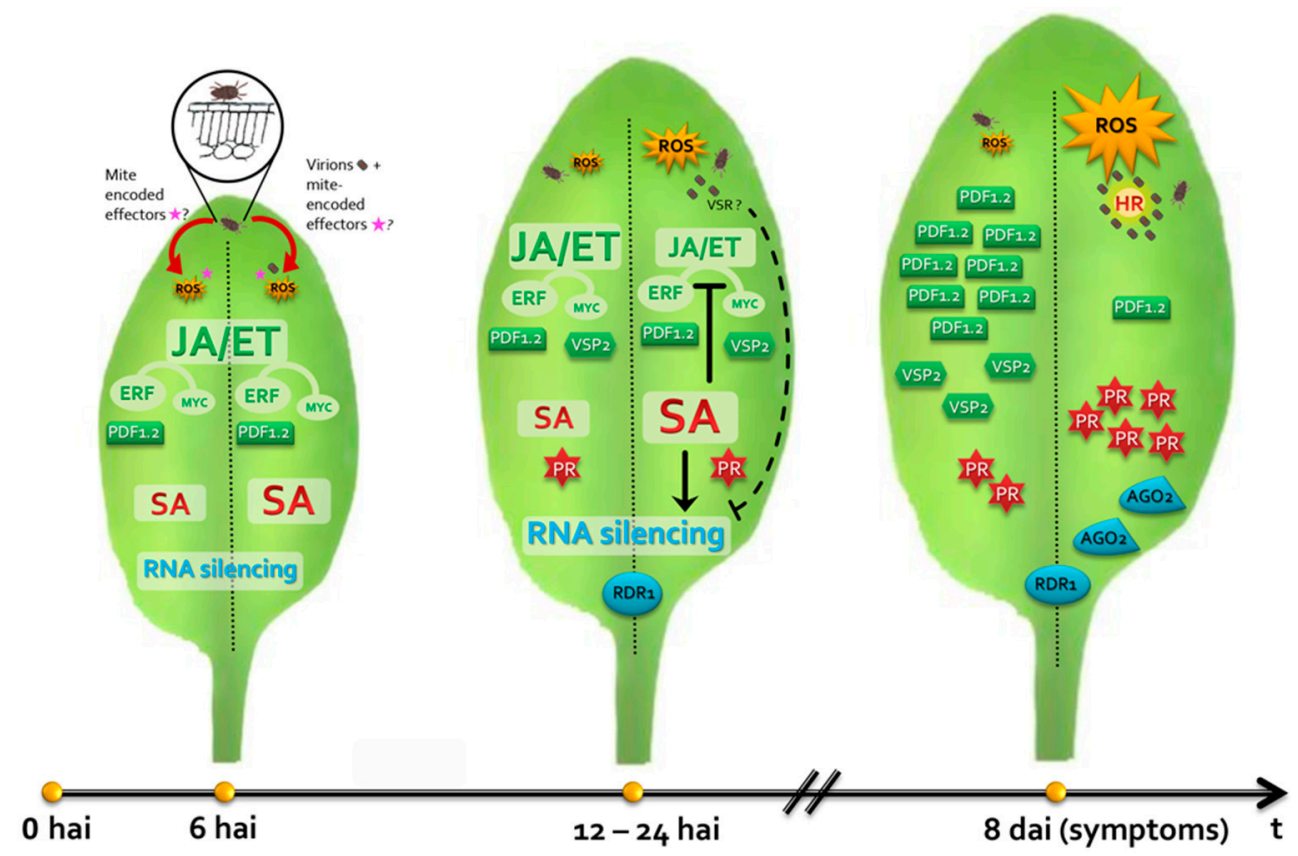

FIGURE 7 | Model representing the interaction of Arabidopsis thaliana plants/Brevipalpus mites/CiLV-C. Left and right leaf halves show hallmarks during the plant interaction with non-viruliferous and viruliferous mites, respectively. During the feeding of non-viruliferous mites, saliva and putative mite-encoded effectors are delivered into the mesophyll cells targeted by the mite's stylet. Reactive oxygen species (ROS) burst, localized cell death and SA and JAVET pathways are triggered. Mite induces the expression of the ERF-branch responsive gene PDF1.2 rather than the MYC-branch responsive gene VSP2, which might restrain plant response against herbivores. In plant infested by CiLV-C viruliferous mites, virions reach mesophyll cells mixed with the salivary flow. CiLV-C multiplies in the initially infected cell and locally moves to the neighboring cells. Mite feeding and the increasing viral loads generate a stronger stimulus which intensifies the ROS production, the number of dead cells around the mite feeding site and the SA-mediated response. Increased activity of the SA pathway likely promotes the inhibition of the JA/ET pathways, leading the downregulation of PDF1.2 and VSP2, which probably improve the mite performance. Both non-viruliferous and viruliferous mite infestations induce expression profile changes in the core genes of the gene silencing mechanism. Enhanced SA signaling activity in viral presence may contribute to higher RDR1 expression. A putative virus suppressor of RNA silencing (VSR) may target and inactivate AGO1, leading to the up-regulation of AGO2, which addresses a second antiviral defense line of the RNA silencing. CiLV-C remains restricted at cells surrounding the inoculation site and chlorosis symptoms develop seven to 10 days after inoculation, probably as a result of a hypersensitive-like response (HR) as consequence of an incompatible interaction.

plants, where they were kept for 4 or $6 \mathrm{~h}$. After the inoculation period, mites were removed using a small brush and plants were maintained in a controlled chamber until the development of symptoms. As positive controls, 10 plants were kept infested with viruliferous mites throughout the experiment. The inoculation periods were predetermined considering available data of CiLV$\mathrm{C}$ infection of common bean (Phaseolus vulgaris) plants using viruliferous B. yothersi (Garita, 2013). Plants were evaluated daily for symptoms and CiLV-C infection was evaluated by RT-PCR (Locali et al., 2003) at the end of the experiment.

\section{Time-Course Gene Expression Analysis on Arabidopsis}

A time course gene expression analysis was conducted on plants infested with viruliferous or non-viruliferous mites and on noninfested control plants at 6,12 , and $24 \mathrm{~h}$ after infestation (hai) and at 8 days after infestation (dai), when symptoms were visible. Four-week-old $A$. thaliana Col-0 plants were grouped in sets of 20 individuals and were assigned to each treatment. For infestation, five (viruliferous or non-viruliferous) mites were transferred to each of three expanded rosette leaves per plant using a small brush and a stereoscopic microscope. Infested or control leaves were collected at each time-point; leaf samples from two plants were pooled, totaling 10 biological replicates per treatment per time point. Once collected, leaves were flash-frozen in liquid $\mathrm{N}_{2}$ and stored at $-80^{\circ} \mathrm{C}$ until RNA extraction.

\section{Time-Course Gene Expression Analysis on C. sinensis}

The time course experiment on sweet orange (C. sinensis) seedlings was established with the same infestation treatments and two time points after infestation: 6 hai and 25 dai, corresponding to $100 \%$ inoculate and $100 \%$ symptomatic plants, respectively. Selection of 6 hai as the first time for evaluation was based on previous results of inoculation access period in Arabidopsis obtained in this work, and those described elsewhere using common bean plants (Garita et al., 2013). Twenty plants per treatment were assayed. Fifteen mites were transferred to one leaf per plant, which was previously coated with a wet mixture of wheat flour, plaster and fine sand (1:1:2) as described above (Figure 1) (Rodrigues et al., 2007). Each collected leaf represented an 
independent biological replicate, totaling 20 biological replicates per treatment per time point. Once collected, leaves were flash-frozen in liquid $\mathrm{N}_{2}$ and stored at $-80^{\circ} \mathrm{C}$ until RNA extraction.

\section{RNA Extraction and cDNA Synthesis}

Plant RNA was purified from approximately $100 \mathrm{mg}$ of leaves using the RNeasy Plant Mini Kit (Qiagen, Venlo, Netherlands). Residual plant DNA was removed by RNAse free DNAse (Qiagen, Venlo, Netherlands) during RNA extraction. RNA quantification and $A_{260} / A_{280}$ ratios were estimated using the NanoDrop ND8000 micro-spectrophotometer (Thermo Scientific, Waltham, MA, USA). RNA integrity was evaluated in $1.2 \%$ agarose gels and the removal of genomic DNA was confirmed by reverse transcription (RT-) PCR assays using the RNA as template. cDNA corresponding to each sample (500 ng of total RNA) was generated using the RevertAid $\mathrm{H}$ Minus First Strand cDNA Synthesis Kit (Thermo Scientific, Waltham, MA, USA) as described by the manufacturer. cDNA solutions were diluted 25-fold in RNAse-free water for subsequent analysis by qPCR.

\section{CiLV-C Detection and Quantification}

CiLV-C loads were assessed by RT-qPCR using a TaqMan ${ }^{\circledR}$ probe complementary to the viral p29 ORF (G.D. Arena, P.L. RamosGonzález, M.A. Machado, J. Freitas-Astúa, unpublished data). Reaction mixes were prepared as recommended by the TaqMan ${ }^{\circledR}$ Fast Universal PCR MasterMix 2X kit manufacturer (Thermo Scientific, Waltham, MA, USA) and the amplifications were carried out in a 7500 Fast Real-Time PCR System device (Thermo Scientific, Waltham, MA, USA). Each sample was analyzed in triplicate and three template-free controls were performed for each primer pair. Cq-values were compared with a standard curve to determine absolute quantities of CiLV-C p29 molecules. Absolute $p 29$ quantities in infected A. thaliana and C. sinensis were normalized using the expression levels of the speciesspecific SAND genes as references. Average of the p29 quantities of each time point were statistically compared with one-way ANOVA and Tukey's HSD (honest significant difference) tests $(\alpha<0.05)$.

\section{Reference Genes Evaluation}

Six candidate genes were selected for expression stability analyses based on previous data obtained from A. thaliana subjected to different stresses (Czechowski et al., 2005) or virus infection (Lilly et al., 2011) or considering the expression profile of their Citrus spp. homolog during the infection with CiLV-C (Mafra et al., 2012). The candidates EF1A, F-BOX, GAPDH, PPR, $S A N D$, and TIP41 were amplified using the primer pairs listed in Supplementary Table 1. Expression levels were assessed by RT-qPCR in Arabidopsis plants infested by either viruliferous or non-viruliferous mites and in non-infested plants. Cq-values and relative quantities were determined as described below for gene expression analysis. Cq-values were imported into geNorm software (Vandesompele et al., 2002) for stability analysis and further selection of the reference genes with the lowest $M$-values.

\section{Gene Expression Analysis}

Transcript levels of defense-related genes were assessed by RTqPCR. All primer sequences were obtained from the literature (Supplementary Table 1) and validated by PCR and RT-qPCR. RT-qPCR mixes were prepared for a final volume of $25 \mathrm{uL}$ with 10 uL of GoTaq qPCR Master Mix (Promega, Madison, WI, USA), 120 or $150 \mathrm{nM}$ of each gene-specific primer pair and $3 \mathrm{uL}$ of the diluted cDNA. Amplifications were performed in a 7500 Fast Real-Time PCR System (Thermo Scientific, Waltham, MA, USA) device, using the standard thermal profile: $95^{\circ} \mathrm{C}$ for $20 \mathrm{~s}$ followed by 40 cycles of $95^{\circ} \mathrm{C}$ for $3 \mathrm{~s}$ and $60^{\circ} \mathrm{C}$ for $30 \mathrm{~s}$. Each sample was analyzed in triplicate. To confirm the absence of genomic DNA and unspecific reactions, the dissociation curves of each reaction was inspected and three template-free controls were included for each primer pair. After this, primer efficiency and quantification cycle values were determined for individual RT-qPCR using the algorithm of the Real-time PCR Miner (Zhao and Fernald, 2005). Gene expression analyses were performed according the $\Delta \mathrm{Cq}$ model using multiple reference genes (Hellemans et al., 2007). The efficiency value (E) of each primer pair was estimated as the arithmetic mean of values from all samples. The Cq-value of each sample, expressed as the mean of the three technical replicates, was converted into relative quantities (RQ) using the function $\mathrm{RQ}=\mathrm{E}^{\Delta \mathrm{Cq}}$, where $\Delta \mathrm{Cq}$ is the difference between the lowest Cq-value across all samples for the evaluated gene and the Cq-value of a given sample. A normalization factor (NF) for each sample was calculated by the geometric mean of the RQ-values of the three reference genes. Normalized-relative quantity (NRQ) of each sample was calculated as the ratio of the sample RQ and the appropriate NF. Individual fold change values were determined by dividing the sample NRQ by the mean NRQ of samples of the calibrator, that is, non-infested control plants; this procedure renders a mean fold change value of 1 for the set of plants in the non-infested treatment. For statistical analysis, one-way ANOVA and Tukey's HSD test ( $\alpha$ $<0.05$ ) were used to compare the mean expression levels of the treatments. Statistical analysis was individually done for each gene at each time-point. For the EDS5 and NHL10 genes, the number of transcripts in mite-free plants was lower than the detection limit of the assay. In those cases, Cq-values were not determined and the data of mite-infested plants were considered as highly significant.

\section{Histochemical Detection of $\mathrm{H}_{2} \mathrm{O}_{2}$ and Cell Death}

Histochemical analyses of Arabidopsis plants were carried out in a time course manner with the same infestation treatments and time points of the gene expression analysis. Ten plants per treatment combination were assayed. Five mites were transferred to each of two expanded rosette leaves per plant. Each infested leaf of a plant was assayed for $\mathrm{H}_{2} \mathrm{O}_{2}$ production or cell death. Dead cells were visualized by staining with trypan blue (Martinez de Ilarduya et al., 2003). Infested or control leaves were boiled in the presence of lactophenol-trypan blue for $2 \mathrm{~min}$ and incubated overnight at room temperature. Excess dye was removed with chloral hydrate $(2.5 \mathrm{~g} / \mathrm{mL})$ for 4 days. $\mathrm{H}_{2} \mathrm{O}_{2}$ was detected by 
staining with DAB (Martinez de Ilarduya et al., 2003). Leaves were vacuum infiltrated for seconds and incubated for $5 \mathrm{~h}$ in the dark to allow the infiltration of DAB. Tissues were boiled in a mix of ethanol:acetic acid (3:1) for $15 \mathrm{~min}$. Samples were examined under bright-field light using an Olympus MVX10 (Olympus, Tokyo, Japan) microscope and images were capture with an Olympus DP71 (Olympus, Tokyo, Japan) camera. Brownish areas were measured with the QUANT software (Vale et al., 2003).

\section{Biology Behavior of Viruliferous and Non-viruliferous Mites in Wild Type Arabidopsis Plants}

Two groups of 15 and 11 healthy Arabidopsis Col-0 plants were infested with CiLV-C viruliferous or non-viruliferous Brevipalpus yothersi mites, respectively. Five mites were transferred to each of three expanded rosette leaves of each plant (primary infestation), completing fifteen mites per plant. Sources of mites and their manipulation were described above. After 13 days of infestation, plant leaves were carefully detached, and the number of Brevipalpus eggs and adults were counted. The number of eggs and mites found in the primary infested leaves were compared to those found in the rest of the leaves (secondary infestation) using the Mann Whitney non-parametric test implemented in R. Furthermore, the same data were compared using t-test, with similar results. For the parametric test, data were normalized following $\ln (\mathrm{x})$ transformation. Presence or absence of CiLV-C in leaf samples was confirmed by RT-qPCR as described above.

\section{REFERENCES}

Abe, H., Tomitaka, Y., Shimoda, T., Seo, S., Sakurai, T., Kugimiya, S., et al. (2012). Antagonistic plant defense system regulated by phytohormones assists interactions among vector insect, thrips and a tospovirus. Plant Cell Physiol. 53, 204-212. doi: $10.1093 / \mathrm{pcp} / \mathrm{pcr} 173$

Aelbrecht, T., Vuylsteke, M., Bauwens, M., Van Houdt, H., and Depicker, A. (2006). Introduction of silencing-inducing transgenes does not affect expression of known transcripts. FEBS Lett. 580, 4154-4159. doi: 10.1016/j.febslet.2006.06.063

Alamillo, J. M., Saénz, P., and García, J. A. (2006). Salicylic acid-mediated and RNA-silencing defense mechanisms cooperate in the restriction of systemic spread of plum pox virus in tobacco. Plant J. 48, 217-227. doi: 10.1111/j.1365-313X.2006.02861.x

Alazem, M., and Lin, N.-S. (2015). Roles of plant hormones in the regulation of host-virus interactions. Mol. Plant Pathol. 16, 529-540. doi: 10.1111/mpp.12204

Alba, J. M., Schimmel, B. C., Glas, J. J., Ataide, L. M., Pappas, M. L., Villarroel, C. A., et al. (2015). Spider mites suppress tomato defenses downstream of jasmonate and salicylate independently of hormonal crosstalk. New Phytol. 205, 828-840. doi: $10.1111 / \mathrm{nph} .13075$

Alberti, G., and Kitajima, E. W. (eds.). (2014). "Anatomy and fine structure of Brevipalpus mites (Tenuipalpidae) - economically important plant-virus vectors - Part 1: An update on the biology and economic importance of Brevipalpus mites," in Zoologica, Vol. 160 (Stuttgart: Schweizerbart Science Publishers), 1-10.

Ali, J. G., and Agrawal, A. A. (2012). Specialist versus generalist insect herbivores and plant defense. Trends Plant Sci. 17, 293-302. doi: 10.1016/j.tplants.2012.02.006

Anderson, J. P., Badruzsaufari, E., Schenk, P. M., Manners, J. M., Desmond, O. J., Ehlert, C., et al. (2004). Antagonistic interaction between abscisic acid and jasmonate-ethylene signaling pathways modulates defense gene

\section{AUTHOR CONTRIBUTIONS}

GA, PR, and JF conceived and designed the experiments; GA, $\mathrm{PR}$, and MN performed the experiments; GA, PR, MR, LC, and JF analyzed the data; EK, MR, MM, and JF contributed with reagents/materials/analysis tools; GA, PR, and JF wrote the paper.

\section{FUNDING}

The authors are grateful to CNPq and FAPESP for scholarships and research grants associated to this work (FAPESP 2012/18771$0,2014 / 00366-8,2008 / 57909-2$ and 2014/08458-9; CNPq 573848/08-4 and 375843/2012-4).

\section{ACKNOWLEDGMENTS}

Authors thank Drs. Valdenice M. Novelli (Centro APTA Citros Sylvio Moreira-IAC) for providing the mite population, Jeferson L. C. Mineiro (Instituto Biológico, Campinas, SP), and Denise Navia (Embrapa Genetic Resources and Biotechnology) for identifying B. yothersi, and João Paulo R. Marques (Esalq-USP) for helping with the histochemical analyses.

\section{SUPPLEMENTARY MATERIAL}

The Supplementary Material for this article can be found online at: http://journal.frontiersin.org/article/10.3389/fpls.2016. 01757/full\#supplementary-material expression and disease resistance in Arabidopsis. Plant Cell 16, 3460-3479. doi: 10.1105/tpc.104.025833

Andrade, D. J., Falconi, R. S., Siqueira, D. S., Barbosa, C. L., Ferraudo, A. S., and Oliveira, C. A. (2013). The influence of citrus rootstocks on the relationship between the mite Brevipalpus phoenicis and citrus leprosis disease. Pest Manag. Sci. 69, 81-87. doi: 10.1002/ps.3365

Arena, G. D., Bergamini, M. P., Tassi, A. D., Kitajima, E. W., Kubo, K. S., and Freitas-Astúa, J. (2013). Citrus leprosis virus C infects Arabidopsis thaliana, the model for plant-pathogen interactions. J. Plant Pathol. 95:448. doi: 10.4454/JPP.V95I2.003

Arimura, G.-I., Ozawa, R., and Maffei, M. E. (2011). Recent advances in plant early signaling in response to herbivory. Int. J. Mol. Sci. 12, 3723-3739. doi: 10.3390/ijms12063723

Azevedo, J., Garcia, D., Pontier, D., Ohnesorge, S., Yu, A., Garcia, S., et al. (2010). Argonaute quenching and global changes in Dicer homeostasis caused by a pathogen-encoded GW repeat protein. Genes Dev. 24, 904-915. doi: 10.1101/gad.1908710

Barrero, J. M., Millar, A. A., Griffiths, J., Czechowski, T., Scheible, W. R., Udvardi, M., et al. (2010). Gene expression profiling identifies two regulatory genes controlling dormancy and ABA sensitivity in Arabidopsis seeds. Plant J. 61, 611-622. doi: 10.1111/j.1365-313X.2009.04088.x

Bastianel, M., Novelli, V. M., Kitajima, E. W., Kubo, K. S., Bassanezi, R. B., Machado, M. A., et al. (2010). citrus leprosis: centennial of an unusual mite-virus pathosystem. Plant Dis. 94, 284-292. doi: 10.1094/PDIS-943-0284

Beard, J. J., Ochoa, R., Braswell, W. E., and Bauchan, G. R. (2015). Brevipalpus phoenicis (Geijskes) species complex (Acari: Tenuipalpidae)-a closer look. Zootaxa 3944, 1-67. doi: 10.11646/zootaxa.3944.1.1

Belliure, B., Janssen, A., Maris, P. C., Peters, D., and Sabelis, M. W. (2004). Herbivore arthropods benefit from vectoring plant viruses. Ecol. Lett. 8, 70-79. doi: 10.1111/j.1461-0248.2004.00699.x 
Bensoussan, N., Santamaria, M. E., Zhurov, V., Diaz, I., Grbic, M., and Grbic, V. (2016). Plant-herbivore interaction: dissection of the cellular pattern of Tetranychus urticae feeding on the host plant. Front. Plant Sci. 7:1105. doi: 10.3389/fpls.2016.01105

Bischoff, V., Cookson, S. J., Wu, S., and Scheible, W.-R. (2009). Thaxtomin A affects CESA-complex density, expression of cell wall genes, cell wall composition, and causes ectopic lignification in Arabidopsis thaliana seedlings. J. Exp. Bot. 60, 955-965. doi: 10.1093/jxb/ern344

Boudsocq, M., Willmann, M. R., McCormack, M., Lee, H., Shan, L., He, P., et al. (2010). Differential innate immune signalling via $\mathrm{Ca}^{(2+)}$ sensor protein kinases. Nature 464, 418-422. doi: 10.1038/nature08794

Brotman, Y., Lisec, J., Méret, M., Chet, I., Willmitzer, L., and Viterbo, A. (2012). Transcript and metabolite analysis of the Trichoderma-induced systemic resistance response to Pseudomonas syringae in Arabidopsis thaliana. Microbiology 158, 139-146. doi: 10.1099/mic.0.052621-0

Bruessow, F., Gouhier-Darimont, C., Buchala, A., Metraux, J.-P., and Reymond, P. (2010). Insect eggs suppress plant defence against chewing herbivores. Plant J. 62, 876-885. doi: 10.1111/j.1365-313X.2010.04200.x

Caarls, L., Pieterse, C. M. J., and Van Wees, S. C. (2015). How salicylic acid takes transcriptional control over jasmonic acid signaling. Front. Plant Sci. 6:170. doi: $10.3389 /$ fpls.2015.00170

Camejo, D., Guzmán-Cedeño, Á., and Moreno, A. (2016). Reactive Oxygen Species, essential molecules, during plant-pathogen interactions. Plant Physiol. Biochem. 103, 10-23. doi: 10.1016/j.plaphy.2016.02.035

Carbonell, A., and Carrington, J. C. (2015). Antiviral roles of plant ARGONAUTES. Curr. Opin. Plant Biol. 27, 111-117. doi: 10.1016/j.pbi.2015.06.013

Casteel, C. L., and Falk, B. W. (2016). "Plant virus-vector interactions: more than just for virus transmission," in Current Research Topics in Plant Virology, eds A. Wang and X. Zhou (Cham: Springer International Publishing), 217-240. doi: 10.1007/978-3-319-32919-2_9

Casteel, C. L., Yang, C., Nanduri, A. C., De Jong, H. N., Whitham, S. A., and Jander, G. (2014). The NIa-Pro protein of Turnip mosaic virus improves growth and reproduction of the aphid vector, Myzus persicae (green peach aphid). Plant J. 77, 653-663. doi: 10.1111/tpj.12417

Chaudhary, R., Atamian, H. S., Shen, Z., Briggs, S. P., and Kaloshian, I. (2014). GroEL from the endosymbiont Buchnera aphidicola betrays the aphid by triggering plant defense. Proc. Natl. Acad. Sci. U.S.A. 111, 8919-8924. doi: $10.1073 /$ pnas. 1407687111

Chen, H., Xue, L., Chintamanani, S., Germain, H., Lin, H., Cui, H., et al. (2009). ETHYLENE INSENSITIVE3 and ETHYLENE INSENSITIVE3-LIKE1 repress SALICYLIC ACID INDUCTION DEFICIENT2 expression to negatively regulate plant innate immunity in Arabidopsis. Plant Cell 21, 2527-2540. doi: $10.1105 /$ tpc. 108.065193

Childers, C. C., French, J. V., and Rodrigues, J. C. V. (2003a). Brevipalpus californicus, B. obovatus, B. phoenicis, and B. lewisi (Acari: Tenuipalpidae): a review of their biology, feeding injury and economic importance. Exp. Appl. Acarol. 30, 5-28. doi: 10.1023/B:APPA.0000006543.34042.b4

Childers, C. C., Rodrigues, J. C. V., and Welbourn, W. C. (2003b). Host Plants of Brevipalpus californicus, B. obovatus, and B. phoenicis (Acari: Tenuipalpidae) and their potential involvement in the spread of viral diseases vectored by these mites. Exp. Appl. Acarol. 30, 29-105. doi: 10.1023/B:APPA.0000006544.10072.01

Coll, N. S., Epple, P., and Dangl, J. L. (2011). Programmed cell death in the plant immune system. Cell Death Differ. 18, 1247-1256. doi: 10.1038/cdd.2011.37

Cui, H., Tsuda, K., and Parker, J. E. (2015). Effector-triggered immunity: from pathogen perception to robust defense. Annu. Rev. Plant Biol. 66, 487-511. doi: 10.1146/annurev-arplant-050213-040012

Czechowski, T., Bari, R. P., Stitt, M., Scheible, W.-R., and Udvardi, M. K. (2004). Real-time RT-PCR profiling of over 1400 Arabidopsis transcription factors: unprecedented sensitivity reveals novel root- and shoot-specific genes. Plant J. 38, 366-379. doi: 10.1111/j.1365-313X.2004.02051.x

Czechowski, T., Stitt, M., Altmann, T., and Udvardi, M. K. (2005). Genomewide identification and testing of superior reference genes for transcript normalization. Plant Physiol. 139, 5-17. doi: 10.1104/pp.105.063743

Erb, M., Meldau, S., and Howe, G. A. (2012). Role of phytohormones in insect-specific plant reactions. Trends Plant Sci. 17, 250-259. doi: $10.1016 /$ j.tplants.2012.01.003
Foyer, C. H., and Noctor, G. (2005). Oxidant and antioxidant signalling in plants: a re-evaluation of the concept of oxidative stress in a physiological context. Plant Cell Environ. 28, 1056-1071. doi: 10.1111/j.1365-3040.2005.01327.x

Foyer, C. H., and Noctor, G. (2013). Redox signaling in plants. Antioxid. Redox Signal. 18, 2087-2090. doi: 10.1089/ars.2013.5278

Garita, L. C. (2013). Relação Vírus-Vetor-Hospedeira no Patossistema da Leprose dos Citros. Available online at: http://www.teses.usp.br/teses/disponiveis/11/11135/ tde-18042013-165710/pt-br.php [Accessed July 15, 2016].

Garita, L. C., Tassi, A. D., Calegario, R. F., Freitas-Astúa, J., Salaroli, R. B., Romão, G. O., et al. (2014). Experimental host range of Citrus leprosis virus C (CiLV-C). Trop. Plant Pathol. 39, 43-55. doi: 10.1590/S1982-56762014005000004

Garita, L., Tassi, A. D., Calegario, R. F., Kitajima, E. W., Carbonell, S. A. M., and Freitas-Astúa, J. (2013). Common bean (Phaseolus vulgaris L.): experimental local lesion host for citrus leprosis virus C (CiLV-C) and some other cytoplasmic-type Brevipalpus-transmitted viruses. Plant Dis. 97, 1346-1351. doi: 10.1094/PDIS-12-12-1143-RE

Gilroy, S., Białasek, M., Suzuki, N., Górecka, M., Devireddy, A. R., Karpiński, S., et al. (2016). ROS, calcium and electric signals: key mediators of rapid systemic signaling in plants. Plant Physiol. 171, 1606-1615. doi: 10.1104/pp.16. 00434

Gómez-Muñoz, N., Velázquez, K., Vives, M. C., Ruiz-Ruiz, S., Pina, J. A., Flores, R., et al. (2016). The resistance of sour orange to Citrus tristeza virus is mediated by both the salycilic acid and the RNA silencing defense pathways. Mol. Plant Pathol. doi: 10.1111/mpp.12488. [Epub ahead of print].

Gouhier-Darimont, C., Schmiesing, A., Bonnet, C., Lassueur, S., and Reymond, P. (2013). Signalling of Arabidopsis thaliana response to Pieris brassicae eggs shares similarities with PAMP-triggered immunity. J. Exp. Bot. 64, 665-674. doi: $10.1093 /$ jxb/ers362

Gutierrez, L., Bussell, J. D., Pacurar, D. I., Schwambach, J., Pacurar, M. and Bellini, C. (2009). Phenotypic plasticity of adventitious rooting in Arabidopsis is controlled by complex regulation of AUXIN RESPONSE FACTOR transcripts and microRNA abundance. Plant Cell 21, 3119-3132. doi: 10.1105/tpc.108.064758

Harvey, J. J., Lewsey, M. G., Patel, K., Westwood, J., Heimstädt, S., Carr, J. P., et al. (2011). An antiviral defense role of AGO2 in plants. PLoS ONE 6:e14639. doi: 10.1371/journal.pone.0014639

Hellemans, J., Mortier, G., De Paepe, A., Speleman, F., and Vandesompele, J. (2007). qBase relative quantification framework and software for management and automated analysis of real-time quantitative PCR data. Genome Biol. 8:R19. doi: 10.1186/gb-2007-8-2-r19

Hilfiker, O., Groux, R., Bruessow, F., Kiefer, K., Zeier, J., and Reymond, P. (2014). Insect eggs induce a systemic acquired resistance in Arabidopsis. Plant J. 80, 1085-1094. doi: 10.1111/tpj.12707

Hogenhout, S. A., and Bos, J. I. B. (2011). Effector proteins that modulate plant-insect interactions. Curr. Opin. Plant Biol. 14, 422-428. doi: 10.1016/j.pbi.2011.05.003

Hunter, L. J., Westwood, J. H., Heath, G., Macaulay, K., Smith, A. G., Macfarlane, S. A., et al. (2013). Regulation of RNA-dependent RNA polymerase 1 and isochorismate synthase gene expression in arabidopsis. PLoS ONE 8:e66530. doi: 10.1371/journal.pone.0066530

Jaouannet, M., Morris, J. A., Hedley, P. E., and Bos, J. I. B. (2015). Characterization of Arabidopsis transcriptional responses to different aphid species reveals genes that contribute to host susceptibility and non-host resistance. PLoS Pathog. 11:e1004918. doi: 10.1371/journal.ppat.1004918

Jovel, J., Walker, M., and Sanfaçon, H. (2011). Salicylic acid-dependent restriction of Tomato ringspot virus spread in tobacco is accompanied by a hypersensitive response, local RNA silencing, and moderate systemic resistance. Mol. Plant. Microbe. Interact. 24, 706-718. doi: 10.1094/MPMI-09-10-0224

Kant, M. R., Jonckheere, W., Knegt, B., Lemos, F., Liu, J., Schimmel, B. C., et al. (2015). Mechanisms and ecological consequences of plant defence induction and suppression in herbivore communities. Ann. Bot. 115, 1015-1051. doi: $10.1093 / \mathrm{aob} / \mathrm{mcv} 054$

Kazan, K., and Manners, J. M. (2013). MYC2: the master in action. Mol. Plant 6 , 686-703. doi: $10.1093 / \mathrm{mp} / \mathrm{sss} 128$

Kim, S. H., Gao, F., Bhattacharjee, S., Adiasor, J. A., Nam, J. C., and Gassmann, W. (2010). The arabidopsis resistance-like gene SNC1 is activated by mutations in SRFR1 and contributes to resistance to the bacterial effector AvrRps4. PLoS Pathog. 6:e1001172. doi: 10.1371/journal.ppat.1001172 
Kitajima, E. W., and Alberti, G. (eds.). (2014). "Anatomy and fine structure of Brevipalpus mites (Tenuipalpidae) - economically important plant-virus vectors - Part 7: Ultrastructural Detection of Cytoplasmic and Nuclear Types of Brevipalpus-transmitted Viruses," in Zoologica, Vol. 160 (Stuttgart: Schweizerbart Science Publishers), 173-190.

Kitajima, E. W., Rodrigues, J. C. V., and Freitas-Astua, J. (2010). An annotated list of ornamentals naturally found infected by Brevipalpus mite-transmitted viruses. Sci. Agric. 67, 348-371. doi: 10.1590/S0103-90162010000300014

Kuchibhatla, D. B., Sherman, W. A., Chung, B. Y. W., Cook, S., Schneider, G., Eisenhaber, B., et al. (2014). Powerful sequence similarity search methods and in-depth manual analyses can identify remote homologs in many apparently "orphan" viral proteins. J. Virol. 88, 10-20. doi: 10.1128/JVI.02 595-13

León, M. G., Becerra, C. H., Freitas-Astúa, J., Salaroli, R. B., and Kitajima, E. W. (2008). Natural infection of Swinglea glutinosa by the Citrus leprosis virus cytoplasmic type (CiLV-C) in Colombia. Plant Dis. 92, 1364-1364. doi: 10.1094/PDIS-92-9-1364C

Levine, A., Tenhaken, R., and Lamb, C. (1994). H202 from the oxidative burst orchestrates the plant hypersensitive disease resistance response. Cell 79, 583-593.

Lewsey, M. G., Murphy, A. M., Maclean, D., Dalchau, N., Westwood, J. H., Macaulay, K., et al. (2010). Disruption of two defensive signaling pathways by a viral RNA silencing suppressor. Mol. Plant. Microbe. Interact. 23, 835-845. doi: 10.1094/MPMI-23-7-0835

Li, F., and Ding, S.-W. (2006). Virus counterdefense: diverse strategies for evading the RNA-silencing immunity. Annu. Rev. Microbiol. 60, 503-531. doi: 10.1146/annurev.micro.60.080805.142205

Li, M., Li, P., Song, R., and Xu, Z. (2010). An induced hypersensitive-like response limits expression of foreign peptides via a recombinant TMV-based vector in a susceptible tobacco. PLoS ONE 5:e15087. doi: 10.1371/journal.pone.0015087

Li, W., Xu, Y.-P., Zhang, Z.-X., Cao, W.-Y., Li, F., Zhou, X., et al. (2012). Identification of genes required for nonhost resistance to Xanthomonas oryzae pv. oryzae reveals novel signaling components. PLoS ONE 7:e42796. doi: 10.1371/journal.pone.0042796

Lilly, S. T., Drummond, R. S., Pearson, M. N., and MacDiarmid, R. M. (2011). Identification and validation of reference genes for normalization of transcripts from virus-infected Arabidopsis thaliana. Mol. Plant. Microbe. Interact. 24, 294-304. doi: 10.1094/MPMI-10-10-0236

Lindermayr, C., Sell, S., Müller, B., Leister, D., and Durner, J. (2010). Redox regulation of the NPR1-TGA1 system of Arabidopsis thaliana by nitric oxide. Plant Cell 22, 2894-2907. doi: 10.1105/tpc.109.066464

Little, D., Gouhier-Darimont, C., Bruessow, F., and Reymond, P. (2007). Oviposition by pierid butterflies triggers defense responses in Arabidopsis. Plant Physiol. 143, 784-800. doi: 10.1104/pp.106.090837

Locali, E. C., Freitas-Astua, J., de Souza, A. A., Takita, M. A., Astua-Monge, G., Antonioli, R., et al. (2003). Development of a molecular tool for the diagnosis of leprosis, a major threat to citrus production in the Americas. Plant Dis. 87, 1317-1321. doi: 10.1094/PDIS.2003.87.11.1317

Locali-Fabris, E. C., Freitas-Astúa, J., and Machado, M. A. (2011). "Genus cilevirus," in Virus Taxonomy - Ninth Report of the International Committee on Taxonomy of Viruses, eds A. King, M. Adams, E. Carstens, and E. Lefkowitz (London: Elsevier; Avademic Press), 1139-1142.

Locali-Fabris, E. C., Freitas-Astúa, J., Souza, A. A., Takita, M. A., Astúa-Monge, G., Antonioli-Luizon, R., et al. (2006). Complete nucleotide sequence, genomic organization and phylogenetic analysis of Citrus leprosis virus cytoplasmic type. J. Gen. Virol. 87, 2721-2729. doi: 10.1099/vir.0.82038-0

López, A., Ramírez, V., García-Andrade, J., Flors, V., and Vera, P. (2011). The RNA silencing enzyme RNA polymerase $\mathrm{V}$ is required for plant immunity. PLoS Genet. 7:e1002434. doi: 10.1371/journal.pgen.10 02434

Mafra, V., Kubo, K. S., Alves-Ferreira, M., Ribeiro-Alves, M., Stuart, R. M., Boava, L. P., et al. (2012). Reference genes for accurate transcript normalization in citrus genotypes under different experimental conditions. PLoS ONE 7:e31263. doi: 10.1371/journal.pone.0031263

Mafra, V., Martins, P. K., Francisco, C. S., Ribeiro-Alves, M., Freitas-Astúa, J., and Machado, M. A. (2013). Candidatus Liberibacter americanus induces significant reprogramming of the transcriptome of the susceptible citrus genotype. BMC Genomics 14:247. doi: 10.1186/1471-2164-14-247
Mandadi, K. K., and Scholthof, K.-B. G. (2013). Plant immune responses against viruses: how does a virus cause disease? Plant Cell 25, 1489-1505. doi: $10.1105 /$ tpc. 113.111658

Martinez de Ilarduya, O., Xie, Q., and Kaloshian, I. (2003). Aphid-induced defense responses in Mi-1 -mediated compatible and incompatible tomato interactions. Mol. Plant-Microbe Interact. 16, 699-708. doi: 10.1094/MPMI.2003.16.8.699

Marques, J. P., Kitajima, E., Freitas-Astúa, J., and Apezzato-da-Glória, B. (2010). Comparative morpho-anatomical studies of the lesions causedby Citrus leprosis virus on sweet orange. Ann. Brazilian Acad. Sci. 82, 501-511. doi: 10.1590/S0001-37652010000200025

Marques, J. P. R., De Freitas-Astúa, J., Kitajima, E. W., and Appezzatoda-Glória, B. (2007). Lesões foliares e de ramos de laranjeira-doce causadas pela leprose-dos-citros. Pesqui. Agropecuária Bras. 42, 1531-1536. doi: 10.1590/S0100-204X2007001100003

Mauck, K., Bosque-Pérez, N. A., Eigenbrode, S. D., De Moraes, C. M., and Mescher, M. C. (2012). Transmission mechanisms shape pathogen effects on hostvector interactions: evidence from plant viruses. Funct. Ecol. 26, 1162-1175. doi: $10.1111 / j .1365-2435.2012 .02026 . x$

Nunes, M. A., Bergamini, M. P., Coerini, L. F., Bastianel, M., Novelli, V. M., Kitajima, E. W., et al. (2012a). Citrus leprosis virus C naturally infecting Commelina benghalensis, a prevalent monocot weed of citrus orchards in Brazil. Plant Dis. 96, 770-770. doi: 10.1094/PDIS-11-11-0925-PDN

Nunes, M. A., Lameiro, P., Calegario, R. F., Bergamini, M., Fender, L., Kitajima, E. W., et al. (2012b). Tropical spiderwort (Commelina benghalensis L.) as source of inoculum for Citrus leprosis virus C. Citrus Res. Technol. 33, 1-9. doi: 10.5935/2236-3122.20120001

O'Brien, J. A., Daudi, A., Butt, V. S., and Bolwell, G. P. (2012). Reactive oxygen species and their role in plant defence and cell wall metabolism. Planta 236, 765-779. doi: 10.1007/s00425-012-1696-9

Parent, J.-S., Martínez de Alba, A. E., Vaucheret, H., Martinez de Alba, A. E., Vaucheret, H., Martínez de Alba, A. E., et al. (2012). The origin and effect of small RNA signaling in plants. Front. Plant Sci. 3:179. doi: 10.3389 /fpls.2012.00179

Pascon, R. C., Kitajima, J. P., Breton, M. C., Assumpção, L., Greggio, C., Zanca, A. S., et al. (2006). The complete nucleotide sequence and genomic organization of citrus leprosis associated virus, cytoplasmatic type (CiLV-C). Virus Genes 32, 289-298. doi: 10.1007/s11262-005-6913-1

Pieterse, C. M. J., Leon-Reyes, A., Van der Ent, S., and Van Wees, S. C. (2009). Networking by small-molecule hormones in plant immunity. Nat. Chem. Biol. 5, 308-316. doi: 10.1038/nchembio. 164

Pieterse, C. M., Van der Does, D., Zamioudis, C., Leon-Reyes, A., and Van Wees, S. C. (2012). Hormonal modulation of plant immunity. Annu. Rev. Cell Dev. Biol. 28, 489-521. doi: 10.1146/annurev-cellbio-092910-154055

Prager, S. M., Wallis, C., and Trumble, J. T. (2015). Indirect Effects of one plant pathogen on the transmission of a second pathogen and the behavior of its potato psyllid vector. Environ. Entomol. 44, 1065-1075. doi: 10.1093/ee/nvv081

Pumplin, N., and Voinnet, O. (2013). RNA silencing suppression by plant pathogens: defence, counter-defence and counter-counter-defence. Nat. Rev. Microbiol. 11, 745-760. doi: 10.1038/nrmicro3120

Ramos-González, P. L., Chabi-Jesus, C., Guerra-Peraza, O., Breton, M. C., Arena, G. D., Nunes, M. A., et al. (2016). Phylogenetic and molecular variability studies reveal a new genetic clade of Citrus leprosis virus C. Viruses 8:153. doi: $10.3390 / \mathrm{v} 8060153$

Rodrigues, V., Bastianel, M., Kubo, K., Fadel, A. L., Nicolini, F., Novelli, V. M., et al. (2007). Desenvolvimento de um método para a otimização da transmissão experimental do vírus da leprose dos citros. Laranja 28, 29-38.

Roy, A., Hartung, J. S., Schneider, W. L., Shao, J., Leon, M. G., Melzer, M. J., et al. (2015). Role bending: complex relationships between viruses, hosts, and vectors related to citrus leprosis, an emerging disease. Phytopathology 105, 872-884. doi: 10.1094/PHYTO-12-14-0375-FI

Sánchez-Velázquez, E. J., Santillán-Galicia, M. T., Novelli, V. M., Nunes, M. A., Mora-Aguilera, G., Valdez-Carrasco, J. M., et al. (2015). Diversity and genetic variation among Brevipalpus populations from Brazil and Mexico. PLoS ONE 10:e0133861. doi: 10.1371/journal.pone.0133861

Sansregret, R., Dufour, V., Langlois, M., Daayf, F., Dunoyer, P., Voinnet, O., et al. (2013). Extreme resistance as a host counter-counter defense against viral suppression of RNA silencing. PLoS Pathog. 9:e1003435. doi: 10.1371/journal.ppat.1003435 
Sarmento, R. A., Lemos, F., Bleeker, P. M., Schuurink, R. C., Pallini, A., Oliveira, M. G. A., et al. (2011). A herbivore that manipulates plant defence. Ecol. Lett. 14, 229-236. doi: 10.1111/j.1461-0248.2010.01575.x

Schmiesing, A., Emonet, A., Gouhier-Darimont, C., and Reymond, P. (2016). Arabidopsis MYC transcription factors are the target of hormonal salicylic acid/jasmonic acid cross talk in response to pieris brassicae egg extract. Plant Physiol. 170, 2432-2443. doi: 10.1104/pp.16.00031

Song, S., Huang, H., Gao, H., Wang, J., Wu, D., Liu, X., et al. (2014). Interaction between MYC2 and ETHYLENE INSENSITIVE3 modulates antagonism between jasmonate and ethylene signaling in Arabidopsis. Plant Cell 26, 263-279. doi: 10.1105/tpc.113.120394

Su, Q., Preisser, E. L., Zhou, X. M., Xie, W., Liu, B. M., Wang, S. L., et al. (2015). Manipulation of host quality and defense by a plant virus improves performance of whitefly vectors. J. Econ. Entomol. 108, 11-19. doi: $10.1093 /$ jee/tou012

Tautz, D., and Domazet-Lošo, T. (2011). The evolutionary origin of orphan genes. Nat. Rev. Genet. 12, 692-702. doi: 10.1038/nrg3053

Thomma, B. P., Nürnberger, T., and Joosten, M. H. (2011). Of PAMPs and effectors: the blurred PTI-ETI dichotomy. Plant Cell 23, 4-15. doi: $10.1105 /$ tpc. 110.082602

Vale, F. X. R., Fernandes-Filho, E. R., and Liberato, J. R. (2003). "QUANT - a Software for plant disease severity assessment," in Roy E. Gaunt Memorial Workshop on Disease and Crop Loss Assessment (Christchurch).

Vandesompele, J., De Preter, K., Pattyn, F., Poppe, B., Van Roy, N., De Paepe, A., et al. (2002). Accurate normalization of real-time quantitative RT-PCR data by geometric averaging of multiple internal control genes. Genome Biol. 3:RESEARCH0034. doi: 10.1186/gb-2002-3-7-research0034

Verhage, A., Vlaardingerbroek, I., Raaymakers, C., Van Dam, N. M., Dicke, M., Van Wees, S. C. M., et al. (2011). Rewiring of the Jasmonate Signaling Pathway in Arabidopsis during Insect Herbivory. Front. Plant Sci. 2:47. doi: $10.3389 /$ fpls.2011.00047

Villarroel, C. A., Jonckheere, W., Alba, J. M., Glas, J. J., Dermauw, W., Haring, M. A., et al. (2016). Salivary proteins of spider mites suppress defenses in Nicotiana benthamiana and promote mite reproduction. Plant J. 86, 119-131. doi: $10.1111 /$ tpj.13152

Von Saint Paul, V., Zhang, W., Kanawati, B., Geist, B., Faus-Kessler, T., SchmittKopplin, P., et al. (2011). The Arabidopsis glucosyltransferase UGT76B1 conjugates isoleucic acid and modulates plant defense and senescence. Plant Cell 23, 4124-4145. doi: 10.1105/tpc.111.088443

Wan, H., Zhao, Z., Qian, C., Sui, Y., Malik, A. A., and Chen, J. (2010). Selection of appropriate reference genes for gene expression studies by quantitative real- time polymerase chain reaction in cucumber. Anal. Biochem. 399, 257-261. doi: 10.1016/j.ab.2009.12.008

Wang, C., Gao, F., Wu, J., Dai, J., Wei, C., and Li, Y. (2010). Arabidopsis putative deacetylase AtSRT2 regulates basal defense by suppressing PAD4, EDS5 and SID2 expression. Plant Cell Physiol. 51, 1291-1299. doi: 10.1093/pcp/pcq087

Weeks, A. R., Marec, F., and Breeuwer, J. A. (2001). A mite species that consists entirely of haploid females. Science 292, 2479-2482. doi: 10.1126/science.1060411

$\mathrm{Wu}$, J., and Baldwin, I. T. (2010). New insights into plant responses to the attack from insect herbivores. Annu. Rev. Genet. 44, 1-24. doi: 10.1146/annurev-genet-102209-163500

Xia, X.-J., Zhou, Y.-H., Shi, K., Zhou, J., Foyer, C. H., and Yu, J.-Q. (2015). Interplay between reactive oxygen species and hormones in the control of plant development and stress tolerance. J. Exp. Bot. 66, 2839-2856. doi: $10.1093 /$ jxb/erv089

Zarate, S. I., Kempema, L. A., and Walling, L. L. (2007). Silverleaf whitefly induces salicylic acid defenses and suppresses effectual jasmonic acid defenses. Plant Physiol. 143, 866-875. doi: 10.1104/pp.106.090035

Zhang, P.-J., Li, W.-D., Huang, F., Zhang, J.-M., Xu, F.-C., and Lu, Y.B. (2013). Feeding by whiteflies suppresses downstream jasmonic acid signaling by eliciting salicylic acid signaling. J. Chem. Ecol. 39, 612-619. doi: 10.1007/s10886-013-0283-2

Zhao, S., and Fernald, R. D. (2005). Comprehensive algorithm for quantitative real-time polymerase chain reaction. J. Comput. Biol. 12, 1047-1064. doi: $10.1089 / \mathrm{cmb} .2005 .12 .1047$

Zhurov, V., Navarro, M., Bruinsma, K. A., Arbona, V., Santamaria, M. E., Cazaux, M., et al. (2014). Reciprocal responses in the interaction between Arabidopsis and the cell-content-feeding chelicerate herbivore spider mite. Plant Physiol. 164, 384-399. doi: 10.1104/pp.113.231555

Conflict of Interest Statement: The authors declare that the research was conducted in the absence of any commercial or financial relationships that could be construed as a potential conflict of interest.

Copyright (c) 2016 Arena, Ramos-González, Nunes, Ribeiro-Alves, Camargo, Kitajima, Machado and Freitas-Astúa. This is an open-access article distributed under the terms of the Creative Commons Attribution License (CC BY). The use, distribution or reproduction in other forums is permitted, provided the original author(s) or licensor are credited and that the original publication in this journal is cited, in accordance with accepted academic practice. No use, distribution or reproduction is permitted which does not comply with these terms. 